\title{
Social Policy and State Revenues in Mineral-Rich Contexts
}

\section{Citation for published version (APA):}

Bebbington, A., Hinojosa, L., Barrientos, A., \& Addison, T. (2010). Social Policy and State Revenues in MineralRich Contexts. (UNRISD Financing Social Policy Report). United Nations Research Institute for Social Development .

\section{Citing this paper}

Please note that where the full-text provided on Manchester Research Explorer is the Author Accepted Manuscript or Proof version this may differ from the final Published version. If citing, it is advised that you check and use the publisher's definitive version.

\section{General rights}

Copyright and moral rights for the publications made accessible in the Research Explorer are retained by the authors and/or other copyright owners and it is a condition of accessing publications that users recognise and abide by the legal requirements associated with these rights.

\section{Takedown policy}

If you believe that this document breaches copyright please refer to the University of Manchester's Takedown Procedures [http://man.ac.uk/04Y6Bo] or contact uml.scholarlycommunications@manchester.ac.uk providing relevant details, so we can investigate your claim.

\section{OPEN ACCESS}




\section{Social Policy and State Revenues in Mineral-Rich Contexts}

Leonith Hinojosa, Anthony Bebbington, Armando Barrientos and Tony Addison 
This United Nations Research Institute for Social Development (UNRISD) Programme Paper has been produced with the support of the Ford Foundation. UNRISD also thanks the governments of Denmark, Mexico, Norway, Sweden, Switzerland and the United Kingdom for their core funding.

Copyright (c) UNRISD. Short extracts from this publication may be reproduced unaltered without authorization on condition that the source is indicated. For rights of reproduction or translation, application should be made to UNRISD, Palais des Nations, 1211 Geneva 10, Switzerland. UNRISD welcomes such applications.

The designations employed in UNRISD publications, which are in conformity with United Nations practice, and the presentation of material therein do not imply the expression of any opinion whatsoever on the part of UNRISD concerning the legal status of any country, territory, city or area or of its authorities, or concerning the delimitation of its frontiers or boundaries.

The responsibility for opinions expressed rests solely with the author(s), and publication does not constitute endorsement by UNRISD. 


\section{Contents}

$\begin{array}{ll}\text { Acronyms } & \text { ii }\end{array}$

Acknowledgements ii

Summary/Résumé/Resumen iii

Summary

Résumé $\quad$ iii

Resumen $\quad$ iv

Introduction: The Political Economy and Social Policy Regimes of Mineral-Rich Countries 1

$\begin{array}{ll}\text { Mineral dependence and mineral-rich countries } & 2\end{array}$

Social policy and welfare regimes: Underlying concepts $r$

1. Mineral Expansion and Development Outcomes in Developing Countries 4

2. Mineral Wealth and Welfare: Discussions of and Challenges to the Resource Curse Thesis

Implications of the economic dimensions of the resource curse for social policy

Implications of the resource curse political dimension for social policy

Social welfare effects of transnational corporations in the mineral industry

\section{What We Know about the Relationship between Mineral Wealth} and Social Policy

Taxes and royalties

Social policy initiatives in MDCs

4. Toward an Integrative Approach for Understanding the Linkages between State Revenue and Social Policy in Mineral-Wealth Contexts

Future Directions

Annex: Social Insurance and Social Assistance Programmes in Selected Mineral-Dependent Economies (Operating in March 2008)

Bibliography

UNRISD Programme Papers on Social Policy and Development

\section{Figures}

Figure 1: Exploration, production and consumption of oil and natural gas by region, 1995 and 2005

Figure 2: Production and consumption of selected metallic minerals, 1995 and 2005

Figure 3: Crude oil, natural gas and commodity metals price index

\section{Tables}

Table 1: Association between state revenue and mineral export dependence (estimates based on averages for 1995-2005) 


\section{Acronyms}

$\begin{array}{ll}\text { CPIA } & \text { country policy and institutional assessment } \\ \text { CSR } & \text { corporate social responsibility } \\ \text { ECLAC } & \text { Economic Commission for Latin American Countries } \\ \text { ESDS } & \text { Economic and Social Data Service } \\ \text { FDI } & \text { foreign direct investment } \\ \text { GDP } & \text { gross domestic product } \\ \text { HDI } & \text { Human Development Index } \\ \text { ICMM } & \text { International Council of Mining and Metals } \\ \text { IFI } & \text { international financial institution } \\ \text { IMF } & \text { International Monetary Fund } \\ \text { MDC } & \text { mineral-rich developing country } \\ \text { NGO } & \text { non-governmental organization } \\ \text { SC } & \text { social contributions } \\ \text { STEP } & \text { Strategies and Tools against Social Exclusion and Poverty } \\ \text { TIPKG } & \text { taxes on income profits and capital gains } \\ \text { TNC } & \text { transnational corporation } \\ \text { UNCTAD } & \text { United Nations Conference on Trade and Development } \\ \text { UNICEF } & \text { United Nations Children's Fund } \\ \text { UNRISD } & \text { United Nations Research Institute for Social Development } \\ \text { WHO } & \text { World Health Organization } \\ \end{array}$

\section{Acknowledgements}

This paper was discussed in the workshop on Social Policy in Mineral-Rich Countries, organized by UNRISD on April 2008. We are grateful to Anthony Hall (commentator) and the two anonymous peer reviewers. Other comments and questions from Diego Sanchez, Tanja Muller, the workshop participants and UNRISD's staff, in particular Katja Hujo and Elena Gaia, are also greatly acknowledged. All errors are ours. The paper also draws on research done by Leonith Hinojosa and Anthony Bebbington in the Territories, Conflicts and Development in the Andes research programme, supported by the ESRC (Grant Number RES051-27-0191 to A. Bebbington) and Armando Barrientos' research on social policies within the BWPI. 


\section{Summary/Résumé/Resumen}

\section{Summary}

The expansion of extractive industries in developing countries, dominated by large investments, has produced divided opinion and reaction among scholars, policy makers and civil society with regard to its impact on host countries' economic performance, governance and peace. Facing that division, the expectation is that the inflow of resources produced by the industry might create opportunities for mineral-rich developing countries to use social policy, both to mitigate the potential negative effects of mineral production, as well as to enhance their citizens' social welfare. This paper looks at the political economy features of mineral expansion and reviews the "resource curse" literature through a social welfare lens. The authors address the linkages between mineral expansion and social policy, examining three aspects that underpin the basis for the above expectation: first, the extent to which state revenue and mineral export dependence are connected; second, the likely effects of mineral wealth on social expenditure levels and composition, and on the promotion of new social policy initiatives; and, finally, the role that the quality of government plays in determining mineral revenue capture and expenditure.

The approach followed for the examination combines correlation, regression and cluster analysis applied to 74 countries in which the level of export dependence on minerals (fuel and metals) has been superior to 10 per cent in the period 1995-2005. Results of that analysis suggest that there is no conclusive evidence of a general pattern among mineral-rich countries with regard to the linkages between mineral wealth, state revenue and social welfare. However, the negative association between state revenue and level of mineral export dependence, and the positive association between state revenue and social policy found in that analysis-together with insights from case-based literature-point to the necessity of analysing the relationship between mineral wealth and social policy within an integrative approach.

This paper concludes by outlining this approach and bringing together concepts developed around welfare regimes and factors produced in a mineral-led development strategy. It also suggests that the inflow of mineral taxes could produce the basis for transformative social policies and social development, which would overcome the underinvestment in social services and social protection so far seen in most mineral-rich countries. In order to achieve this in a sustainable way, states need also to consider the use of these financial inflows in transforming their economic and institutional structures.

Leonith Hinojosa is Research Associate and Teaching Fellow at the School of Environment and Development. Anthony Bebbington is Professor of Nature, Society and Development at the School of Environment and Development. Armando Barrientos is Research Director at the Brooks World Poverty Institute (BWPI). At the time of writing, Tony Addison was Executive Director of the BWPI. He is now Deputy Director of the United Nations University-World Institute for Development Economics Research (UNU-WIDER). Both the School of Environment and Development and the Brooks World Poverty Institute are at the University of Manchester, United Kingdom.

\section{Résumé}

Les opinions des universitaires, des décideurs et de la société civile - ainsi que leurs réactions sur le sujet - sont divisées sur l'impact des industries extractives, dont l'essor dans les pays en développement est alimenté par de lourds investissements, sur la performance économique, la gouvernance et la paix dans ces pays. Devant cette division, on ne peut qu'espérer qu'avec les rentrées produites par ces industries, les pays en développement riches en ressources minérales aient la possibilité d'utiliser la politique sociale tant pour atténuer les éventuels effets néfastes de cette production que pour améliorer les conditions d'existence de leurs citoyens. Ce document examine les caractéristiques de l'essor minier sous l'angle de l'économie politique et 
la littérature relative à la "malédiction des richesses" du point de vue du bien-être social. Les auteurs traitent des liens entre essor minier et politique sociale, examinant trois aspects dont se nourrit l'espoir exprimé plus haut: premièrement, la mesure dans laquelle les recettes publiques et la dépendance du pays à l'égard des exportations minérales sont liées; deuxièmement, les effets probables de la richesse du sous-sol sur les niveaux et la composition des dépenses sociales et sur le lancement d'initiatives nouvelles de politique sociale et, enfin, le rôle que joue la qualité du gouvernement dans la perception par l'Etat des recettes provenant des richesses minérales et dans la façon de les dépenser.

La démarche retenue pour l'étude combine l'analyse par corrélation, régression et segmentation appliquée à 74 pays dans lesquels les richesses minérales (hydrocarbures et métaux) représentent plus de 10 pour cent du total des exportations dans la période 1995-2005. Cette analyse ne livre aucun élément qui prouverait de façon concluante que les rapports entre ressources minérales, recettes publiques et bien-être social suivent un schéma général constant dans les pays dont le sous-sol est riche. Cependant, l'association négative entre les recettes publiques et la mesure dans laquelle les exportations dépendent des ressources minérales, et l'association positive entre recettes publiques et politique sociale mises en évidence dans cette analyse-ainsi que les lumières apportées par les études de cas contenues dans la littératureindiquent qu'il serait nécessaire d'analyser les rapports entre richesses minérales et politique sociale selon une démarche d'intégration.

Les auteurs concluent en exposant cette démarche et en réunissant des concepts élaborés à propos des régimes sociaux et des facteurs produits dans une stratégie dans laquelle les ressources minérales sont le moteur du développement. Ils suggèrent aussi que les recettes fiscales tirées des ressources minérales pourraient financer des politiques sociales et un développement social qui seraient sources de transformation et mettraient un terme à l'insuffisance des crédits investis dans les services sociaux et la protection sociale observée jusqu'à présent dans la plupart des pays riches en ressources minérales. Pour atteindre durablement ces objectifs, les Etats doivent aussi envisager d'utiliser ces rentrées financières pour transformer leurs structures économiques et institutionnelles.

Leonith Hinojosa est associée de recherche et enseigne à la School of Environment and Development. Anthony Bebbington est titulaire de la chaire Nature, société et développement à la School of Environment and Development. Armando Barrientos est directeur de recherches au Brooks World Poverty Institute (BWPI). Au moment de la rédaction du document, Tony Addison était directeur exécutif du BWPI. Il est maintenant directeur adjoint de l'Université des Nations Unies-Institut mondial de recherche sur les aspects économiques du développement (UNU-WIDER). La School of Environment and Development et le Brooks World Poverty Institute font tous deux partie de l'Université de Manchester, Royaume-Uni.

\section{Resumen}

La expansión de las industrias de extracción en los países en desarrollo, bajo el dominio de las grandes inversiones, ha generado opiniones y reacciones contrapuestas entren intelectual, planificadores y la sociedad civil en cuanto a sus repercusiones sobre el desempeño económico, la gobernanza y la paz de los países receptores. Ante esa diferencia de pareceres, la expectativa es que los recursos que produce la industria podría crear oportunidades para que los países en desarrollo ricos en minerales utilicen la política social para mitigar los posibles efectos adversos de la producción mineral y, al mismo tiempo, mejorar la previsión social para sus ciudadanos. En este documento se examina la expansión de la actividad minera desde la perspectiva de la economía política y se analizan los trabajos que hablan de la "maldición de los recursos" a través del lente de la previsión social. Los autores abordan los vínculos entre la expansión de las actividades mineras y la política social a partir del examen de tres aspectos que conforman la base de la mencionada expectativa: Primero, el grado de relación entre los ingresos del Estado y la dependencia respecto de las exportaciones de minerales; segundo, los posibles efectos de la riqueza mineral sobre los niveles y la composición del gasto social, así como sobre la promoción 
de las nuevas iniciativas de política social; y tercero, el papel que la calidad del gobierno desempeña al momento de determinar cómo se captan e invierten los ingresos generados por la actividad minera.

El criterio utilizado para este análisis combina la correlación, la regresión y el análisis de grupos o "clusters" aplicado a 74 países en los cuales el nivel de dependencia respecto de las exportaciones de minerales (combustibles y metales) ha sido superior al 10 por ciento durante el período 1995-2005. Los resultados de este análisis indican que no se tienen pruebas concluyentes de que exista un patrón general entre los países ricos en minerales que hable de vínculos entre riqueza mineral, ingresos del Estado y previsión social. Sin embargo, la asociación negativa entre los ingresos del Estado y el nivel de dependencia respecto de las exportaciones de minerales, así como la asociación positiva entre los ingresos del Estado y la política social que este análisis permitió observar - junto a los datos extraídos de la bibliografía sobre casos específicos - revelan la necesidad de explorar la relación entre la riqueza mineral y la política social desde una perspectiva integrativa.

El documento concluye con la delimitación de este enfoque y la consolidación de un conjunto de conceptos formulados en torno a regímenes y factores de previsión social producidos en una estrategia de desarrollo basada en la explotación mineral. Además, se señala en este trabajo que los impuestos a la actividad minera podrían formar la base para la formulación de políticas sociales transformativas y el desarrollo social, que permitirían superar las subinversiones en servicios sociales y protección social que hasta la fecha se han observado en la mayoría de los países ricos en minerales. Para alcanzar esta meta de una manera sostenible, los estados deben considerar también utilizar estos flujos de recursos financieros en la transformación de sus estructuras económicas e institucionales.

Leonith Hinojosa es Investigador Asociado y Docente Invitado en la Escuela de Medio Ambiente y Desarrollo. Anthony Bebbington es Profesor de Naturaleza, Sociedad y Desarrollo en la Escuela de Medio Ambiente y Desarrollo. Armando Barrientos es Director de Investigación del Instituto Brooks sobre la Pobreza Mundial (BWPI). Al momento de participar en este trabajo, Tony Addison era Director Ejecutivo del BWPI. Actualmente se desempeña como Director Adjunto del Instituto Mundial de Investigaciones de Economía del Desarrollo, Universidad de las Naciones Unidas. Tanto la Escuela de Medio Ambiente y Desarrollo como el BWPI forman parte de la Universidad de Manchester, Reino Unido. 



\section{Introduction: The Political Economy and Social Policy Regimes of Mineral-Rich Countries}

At the time of writing ${ }^{1}$ it seemed that the different impacts and implications of the recent economic crisis - which occurred mostly in developed economies but was spreading toward the developing world-would also affect mineral-rich developing countries (MDCs) by reducing both demand for, and prices of, minerals and metals. Yet this effect is still to be seen. The economies of mineral-importing countries such as China and India do not seem to be shrinking significantly - at least not to the same extent as those of the countries of the Organisation for Economic Co-operation and Development (OECD). ${ }^{2}$ Furthermore, it is expected that measures taken to prompt economic recovery all over the world will again stimulate the expansion of mineral industries; an expansion that is more likely to occur in MDCs, since the constraints on developing mining activities in Western Europe and North America are stronger (Otto et al. 2007). ${ }^{3}$

That fact, together with the effects of the last boom of mineral prices observed circa 2003-2007, has led to an examination of the extent to which mineral wealth can constitute a source of economic development, with particular emphasis on the fiscal revenue from mineral industries for host developing countries. This has also created expectations with regard to social development-the hope that the tax inflow from mineral commodities will help overcome underinvestment in social services and social protection, and produce the basis for transformative social policies in mineral-rich economies.

At the same time, other observers fear that a significant inflow of investments in the mineral sectors might prove to be a curse. They argue that the availability of large amounts of fiscal resources is in itself not enough to produce development. Instead, how beneficial-or damaging -it could be depends on the capacity of the state to control, extract and allocate resources, as well as its ability to generate consensus around a development strategy based on the exploitation of mineral resources. To date, literature on mineral wealth and development has revealed differences between non-mineral and mineral economies, and the balance of contributions has tended to concur that mineral wealth has been more harmful than helpful.

Thus, the two concerns about the relationship between transformative social policies and mineral development are:

(i) whether revenue from mineral extraction can constitute a sustainable way to implement and finance social policies, and promote welfare regimes that provide progressive redistribution; and

(ii) whether the exploitation of mineral resources undermines the efficient allocation of resources in the economy, weakening the political balance needed to maximize social development and balanced growth.

This paper challenges the determinism of the resource curse hypothesis. It suggests that these two concerns can be addressed by assessing the implications of growth and development strategies based on the expansion of mineral sectors for social welfare, and the extent to which the exploitation of mineral resources has produced the expected effects on government revenue and expenditure. This approach narrows the field of study to MDCs only, and aims to reveal the extent to which the level of mineral export dependence influences social policy making. With that purpose, this paper provides a cross-country analysis of the linkages between state

\footnotetext{
1 June 2009.

2 According to figures from the International Monetary Fund (IMF), the difference in gross domestic product (GDP) decrease between developed and developing economies was about six points since the crisis erupted 2008-2009 (IMF 2009).

3 The United Nations Conference for Trade and Development's (UNCTAD) 2007 report on foreign direct investment (FDI) registers that 76.1 per cent of inward FDI flows, in the 2003-2005 period, went to developing economies' mineral industry.
} 
revenue and social policy in contexts of mineral wealth, and presents an approach to identify those linkages and the effects of a mineral-led development strategy on welfare regimes.

\section{Mineral dependence and mineral-rich countries}

Development literature has not been able to come up with a clear understanding of what constitutes a mineral-rich country. The consensus has been to take some measure of economic dependence on the mineral commodities in question and to assess the level of dependence through the share of mineral exports in either total exports or in gross domestic product (GDP). Even within that consensus, contributors diverge about the boundaries, without much explanation about how the thresholds are established. In practice, a baseline point of 10 per cent share of the mineral sector in total exports has been agreed upon.

In order to review what has been said about MDCs and to provide a statistical analysis of the relationship between state revenue and social policies, this paper adopts the 10 per cent baseline point and establishes the following ranking to classify mineral-dependent countries-high dependence: 40 per cent or more of share of the mineral sector in total exports; medium dependence: 20-39 per cent; low dependence: 10-19 per cent. ${ }^{4}$ It also provides insights on additional criteria that need to be incorporated in order to understand more accurately the implications of identifying a country as "mineral-rich" as opposed to "mineral-dependent". ${ }^{5}$

From a social policy perspective, the distinction between a mineral-dependent and a mineralrich developing country is important. From a political economy perspective, the paper asks who benefits from mineral wealth and how mineral resources are allocated and distributed. As it has been documented in the "resource curse" literature (see section 2), mineral dependence can be harmful, for instance, when it finances corrupt or authoritarian governments without long-term strategies for economic development, and without redistributing revenues to the population in general and to mining communities in particular. The terms mineral abundance or mineral wealth, on the other hand, suggest that mining can be a source of development-mineral wealth is seen as a positive "endowment" (ICMM 2006). It can therefore produce the financial basis for development, for instance, creating fiscal space to develop a welfare state, as well as financing structural economic and social change. Therefore, the expansion of mineral sectors is planned and managed in a way that enhances the potential macroeconomic benefits and offsets the real or potential damage to host economies, the environment and societies. This broader perspective, which simultaneously explores the macroeconomic, institutional and sociopolitical effects of mineral development, suggests that the relationship between social policy and mineral wealth needs to be framed in a holistic approach, which takes into account all impacts that mineral wealth produces in a country.

\section{Social policy and welfare regimes: Underlying concepts}

In development contexts, social policy is a growing concept that has evolved over time, according to changes in the ideological, political and economic frames in which societies develop. In an applied policy arena, it refers to the state's role in enhancing citizens' capabilities, supporting them to cope with risks, and reducing their vulnerability and poverty. This implies, as the United Nations Research Institute for Social Development (UNRISD) suggests, a conception of social policy as "a key instrument that works in tandem with economic policy", and which ensures equitable and socially sustainable development, taking into account the political contexts within which they are formulated and implemented (Mkandawire 2004:3-4). It also implies that the role of the state in social welfare provision in

\footnotetext{
4 The paper also adopts UNCTAD's (2007:84) definition of extractive or mineral industries: "primary activities involved in the extraction of non-renewable resources... .Economic minerals are those that are marketed for productive purposes. [They include]: energy minerals (oil, gas, coal and uranium), metallic minerals, and non-metallic minerals (industrial and construction minerals and precious stones)."

5 Notwithstanding the conceptual difference between mineral-rich and mineral-dependent countries, in this paper both terms are used interchangeably for statistical purposes. That difference is highlighted in specific cases whenever enough information exists to illustrate the argument.
} 
developing countries is not confined to social service delivery. Instead, the state's role in social policy is holistic in nature, addressing "traditional" social welfare issues, such as health, education and social security, and also "non-traditional" social protection and growthenhancing issues (UNRISD 2006). Furthermore, as Hall and Midgley (2004) remark, in addressing livelihood concerns, social policy involves a cross-sector, integrated and holistic approach that links with human rights. In that understanding, the set of institutions needed to achieve social policy goals is broad and, notwithstanding the importance of the state, its role is intertwined with the roles of the market, communities and international organizations. ${ }^{6}$

From this integrative point of view, we agree that social policy is defined by the following central elements.

(i) It is a public policy oriented to the enhancement of the human development of all citizens, by ensuring satisfaction of basic needs and well-being requirements.

(ii) It operates through a wide variety of policy instruments across a number of sectors, which include social protection or safety nets and also growth-enhancing measures; it is particularly focused on socially disadvantaged groups.

(iii) It shapes solidarity through universal provision, so as to build national identity and social cohesion.

(iv) Its formulation and implementation is carried out by a wide range of actors (state, market and communities). Yet, the systematic and deliberate intervention of the state is fundamental, which requires adequate institutions and policies.

(v) Given that a rights-based approach is needed to ensure universal access to social provision (Esping-Andersen 1990), it is expected that through social policy people will be able to maintain a livelihood without strict reliance on the market.

This broad conceptualization of social policy recalls the organizing concept of welfare regimes introduced by Titmuss (1974) and elaborated further by Esping-Andersen (1990, 1999, 2001), that is, a particular mix of social, political and economic arrangements which underlie patterns of stratification and nurture a particular welfare system (for example, liberal, conservative or corporatist, or social democratic in OECD countries). In those regimes, state and market activities are interlocked and each welfare regime is underpinned by the state's history of nation building, as well as by the family's role in social provision.

The application of the concept of welfare regimes to developing countries has been explored by Gough et al. (2004). In an extended version of Esping-Andersen's formulation, Gough and collaborators emphasize the community's role in social welfare provision and describe three forms of welfare regimes.

\begin{abstract}
A welfare state regime reflects a set of conditions where people can reasonably expect to meet their security needs via participation in labour markets, financial markets and the finance and provisioning role of a 'welfare state'.... An informal security regime reflects a set of conditions where people rely heavily upon community and family relationships to meet their security needs, to greatly varying degrees. An insecurity regime reflects a set of conditions which generate gross insecurity and block the emergence of stable informal mechanisms to mitigate, let alone rectify, these (Gough et al. 2004:33-34, authors' emphasis).
\end{abstract}

The paper returns to this reflection on welfare regimes in section 4, where it presents an approach to establishing linkages between social policy and mineral wealth. The approach builds on the theoretical reflection on the transformative role of social policy presented in this

\footnotetext{
${ }^{6}$ Arjan de Haan 2007; Gough et al. 2004; Esping-Andersen 2001.
} 
section, and expands on the particular effects that mineral wealth can produce in the configuration of welfare regimes. The paper also identifies the mechanisms through which government revenue from mineral sectors can affect the structure of a welfare mix, and the institutional responsibilities for welfare provision shared between state, market, community and household.

In order to identify the impact that mineral wealth produces on social welfare, the following sections assess the significance of mineral wealth for state revenue and social policy in MDCs.

\section{Mineral Expansion and Development Outcomes in Developing Countries}

There are a number of features that characterize the mineral sectors and support the assumptions about their constituting a source of economic and social development for mineralrich developing countries. The complexity involved in making a cross-country comparison of the linkages between mineral wealth and welfare is underpinned by strong differences between MDCs, in terms of their economic and welfare indicators, somewhat regardless of their levels of export dependence. For instance, among the $36 \mathrm{MDCs}$ whose level of dependence is relatively high (with ratios higher than 30 per cent of exports), 21 have reached relatively high levels of human development (measured by the Human Development Index/HDI in a range of medium high and high values), while the rest fall in the category of low HDI, despite their mineral wealth. Differences of average GDP per capita are also significant (for example, $\$ 666^{7}$ in the Democratic Republic of the Congo and \$15,397 in Seychelles, while their level of mineral dependence only varies by five points). Growth rates per capita for countries like Azerbaijan and Turkmenistan differ by more than six points, although their mineral dependence differs only by two points. Similarly, between countries that have almost the same mineral export ratios (like Algeria and Nigeria), the poverty gap can range from less than one (in Algeria) to more than 60 (in Nigeria), while the HDI can diverge by 100 per cent.

These differences among MDCs highlight the risks of generalization. This is particularly true for any direct causal relationship between mineral wealth and development outcomes-for instance, in countries like Bolivia, improvements in HDI (currently medium) can also be explained by other factors, such as foreign aid.

Notwithstanding the differences, there are common issues too. These concern the main actors involved in shaping and implementing a mineral wealth-based development strategy (transnational companies, international financial organizations, states), actors who challenge such a strategy (for example, civil society organizations and affected communities), and the contentious and ambiguous conditions under which mineral expansion frequently happens (Bebbington et al. 2008). These issues require examining not only the domestic conditions of MDCs, but also the transnational characteristics of mineral sectors. While some issues are related to intrinsic institutional and endogenous structural factors of development, others relate to exogenous factors conditioning the MDCs' margins of manoeuvre to benefit from their mineral wealth.

The global markets scenario dictates that most mining and hydrocarbons (fuel and gas) projects operate on the basis of economies of scale and, hence, are led by large investors. According to the World Investment Report of the United Nations Conference for Trade and Development (UNCTAD 2007), over the past quarter century, the share of FDI in natural resources and manufacturing declined; however, since 2004, there has been a rebound of FDI in the mineral industries. Figure 1 shows that, in the case of hydrocarbons, exploration has increased in developed countries, while production and consumption have decreased over a span of 10 years. In that sector, figures for developing countries have moved in the opposite direction. In

All references to $\$$ are to US dollars. 
contrast to oil and gas, as can be observed in figure 2, most mining investment has been directed at satisfying the increasing demand from developing Asian countries (whose demand for metals has begun to exceed that of developed countries) as well as of developed countries.

Figure 1: Exploration, production and consumption of oil and natural gas by region, 1995 and 2005 (per cent)

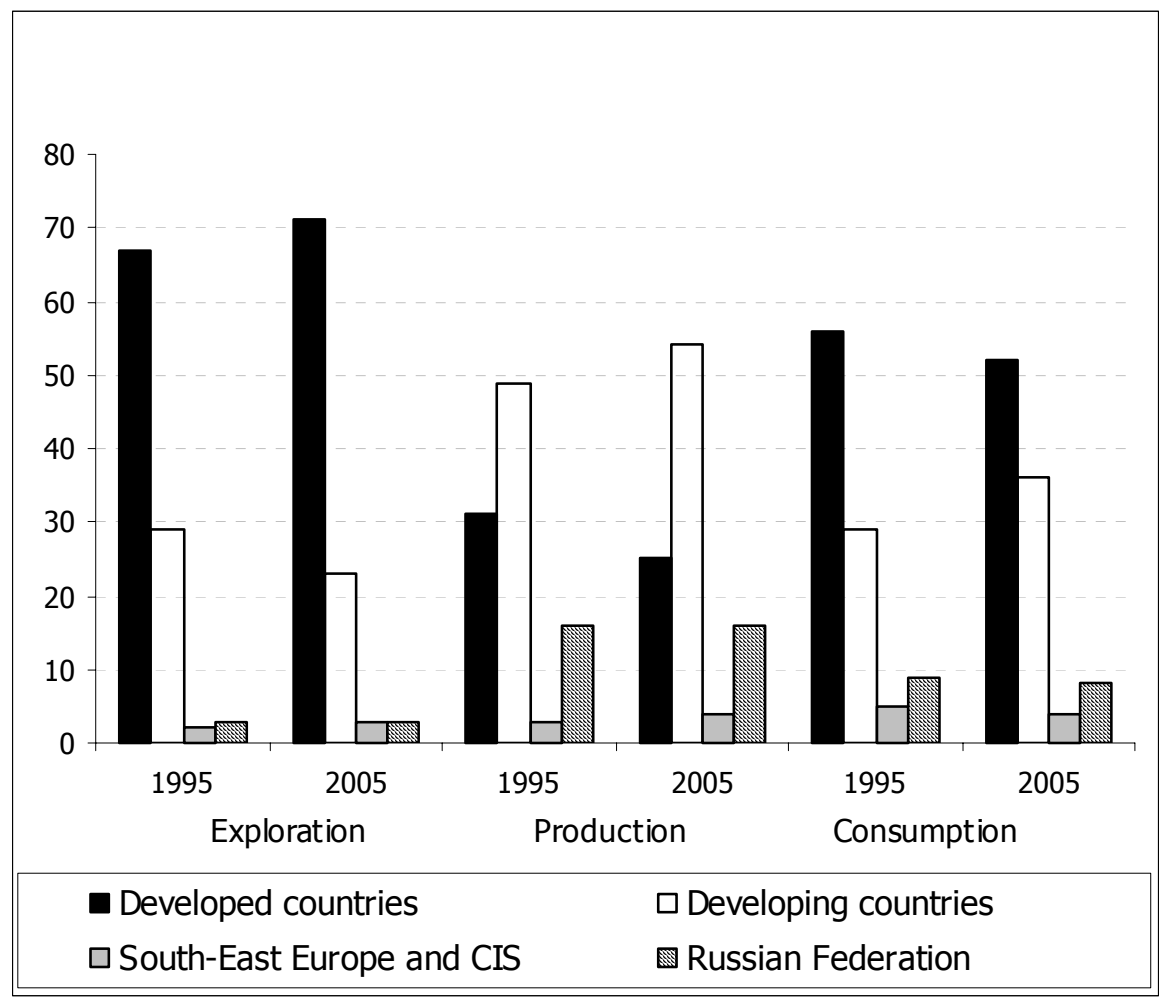

Figure 2: Production and consumption of selected metallic minerals, 1995 and 2005 (per cent)

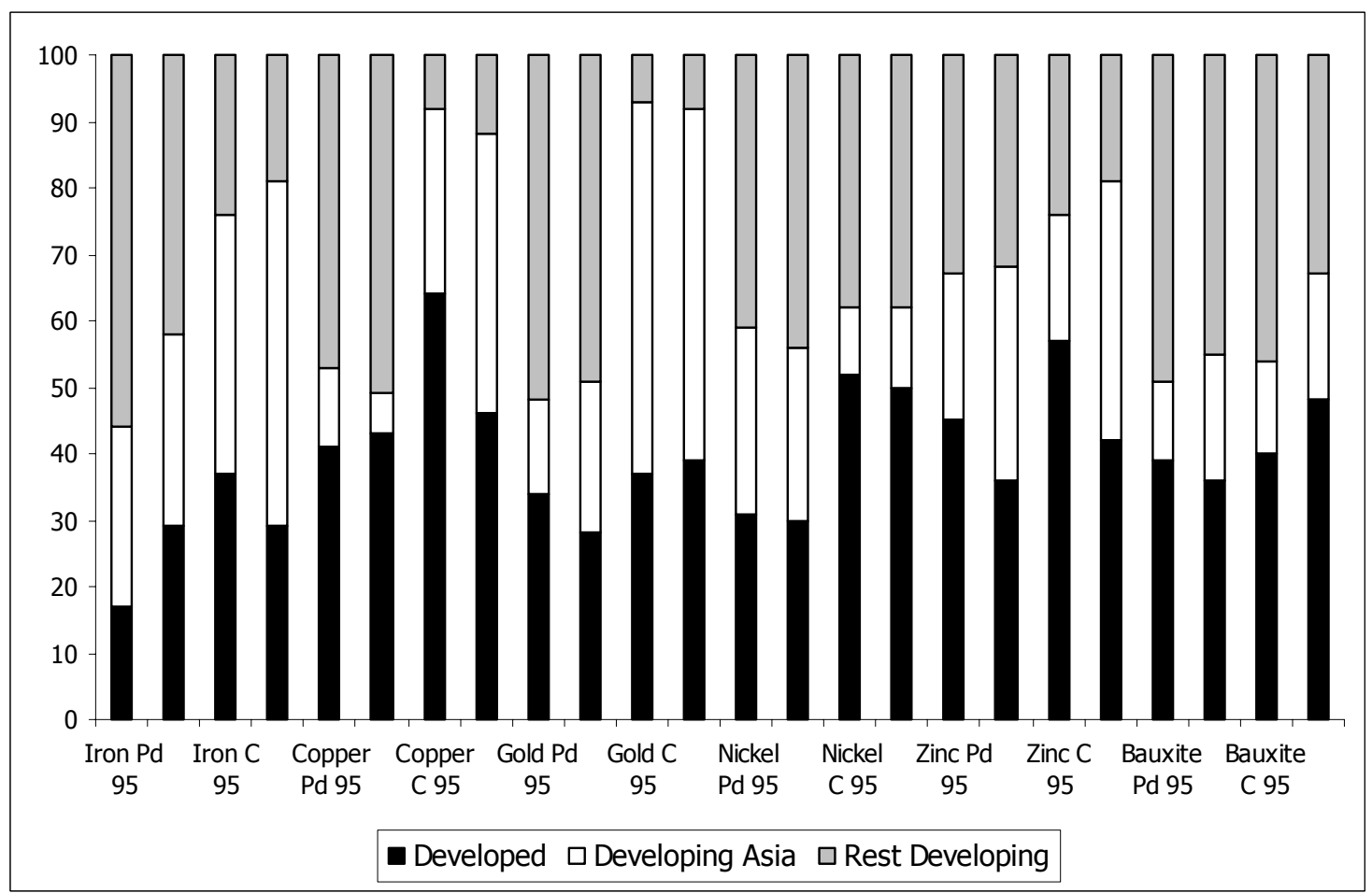

Note: $\mathrm{P}=$ production. $\mathrm{C}=$ consumption 
As a result of the trend-observed since the early 1990s - to move the production of minerals into developing countries, the major corporations have gone into new areas of South America, Southeast Asia and Africa in order to expand their access to mineral areas currently under exploitation and to increase exploration efforts.

\section{Mineral Wealth and Welfare: Discussions of and Challenges to the Resource Curse Thesis}

The "resource curse" thesis that emerged in the early 1990s (Auty 1993, 2001; Sachs and Warner 1995) suggests that an abundance of natural resources generates distortions in the economic and political structures of the countries in which the resources are based. In its economic dimension, the thesis tries to explain a certain pattern of poor economic performance observed in mineralrich countries since the 1970s. It elaborates on the Dutch disease effect (see below), enclave economies and lack of diversification, the crowding-out effects on human capital, and, more recently observed, the effects of natural resources depletion and environmental damage caused by mineral exploitation. In its political dimension, the thesis hinges on the conflicts within national and regional societies that are provoked by the eagerness among domestic elites to benefit from mineral rents; the impact of corporations on national sovereignty; and claims about a range of other negative effects on governance issues related to taxation basis, state-citizen relationships and corruption.

Although the thesis has subsequently been contested on methodological and empirical grounds, ${ }^{8}$ concluding that there is not enough evidence for a deterministic negative relationship between mineral wealth and development, the multiple claims that have been made about the ironic misfortune of mineral-rich countries challenge the counterclaim of the potential of mineral wealth to foster social policy and social welfare (as suggested by the World Bank 1996, 2005 and ICMM 2006, among others).

\section{Implications of the economic dimensions of the resource curse for social policy}

\section{Dutch disease and weak sector diversification}

The Dutch disease effect-named after the disappointing economic experience of the Netherlands and the United Kingdom after the discovery of North Sea oil in the 1970ssuggests that, during boom periods, mineral wealth originates patterns of overconsumption and low-return investments which are difficult to sustain through subsequent downswings. Distortions in exchange rates and wage levels, originated by large inflows of foreign exchange, undermine the growth potential of non-mineral tradable sectors (for example, manufacturing) and concentrate the economic structure around enclave economies of finite duration. The greater the natural resource endowment, the higher is the demand for non-tradable goods; consequently, allocation of labour and capital to the manufacturing sector decreases (Sachs and Warner 1995).

The political effects of sectoral economic concentration-together with a dominant presence of transnational corporations (TNCs) - are reckoned to trigger political contests for capturing easily identifiable revenue and to induce biased spending in governments, based on political pressure to rapidly channel that revenue into the domestic economy (Auty and Gelb 2001). Cases explored by Auty (2008) illustrate that the distribution of revenue has fed the overexpansion of bureaucracy, and induced patronage and graft that has corroded the quality of government. Revenue has also been transferred to powerful vested interests in the industrial sectors. Furthermore, these interests, once entrenched in government, oppose any move toward more redistributive reforms, precisely because they benefit from the existence of inefficient schemes of revenue distribution (Ross 2001).

\footnotetext{
${ }^{8}$ See, for instance, Davis (1995); Brunnschweiler and Bulte (2008); Stijns (2005); and Rosser (2009).
} 
The implications of all the above for the development of social welfare schemes and policies are several. First, the Dutch disease effect, if not managed successfully with a tight monetary policy (IMF 2007) or a restrictive fiscal policy (as Sarraf and Jiwanji 2001 illustrate in their study on Botswana), offsets the benefits derived from expansionary periods. This can harm the state's ability to produce a sustainable basis for social policy, and can constrain the possibilities of developing a welfare state regime. These effects can be exacerbated by enclave economies and the lack of diversification, and can reduce the chances of sustaining a welfare state regime beyond the lifetime of the mineral economy. A further effect might also be to undermine the basis of an informal security regime, particularly if employment opportunities in non-mineral sectors of the economy are reduced in the long run. Third, inefficient schemes of mineral revenue distribution imply a waste of fiscal resources. This effect can reinforce the regressive income distribution that characterizes many MDCs, and can further consolidate the economic bases of political power of those interest groups resisting pro-poor redistribution.

\section{Export-dependence and foreign exchange volatility}

The dependence of mineral-rich countries on the exports of these resources makes their economies extremely vulnerable to the types of external shock and price volatility that characterize mineral commodities in global markets (see figure 3). Furthermore, the concentration of the upstream segment of minerals and energy value chains in some specialized developed countries - for instance, the United Kingdom and Canada for the processing of gold, and the oil refineries in the United States and Western Europe-in addition to reducing the share of value that MDCs can obtain in the value chain, also reinforces the lack of sector diversification noted in the previous section.

Figure 3: Crude oil, natural gas and commodity metals price index $(2005=100)$

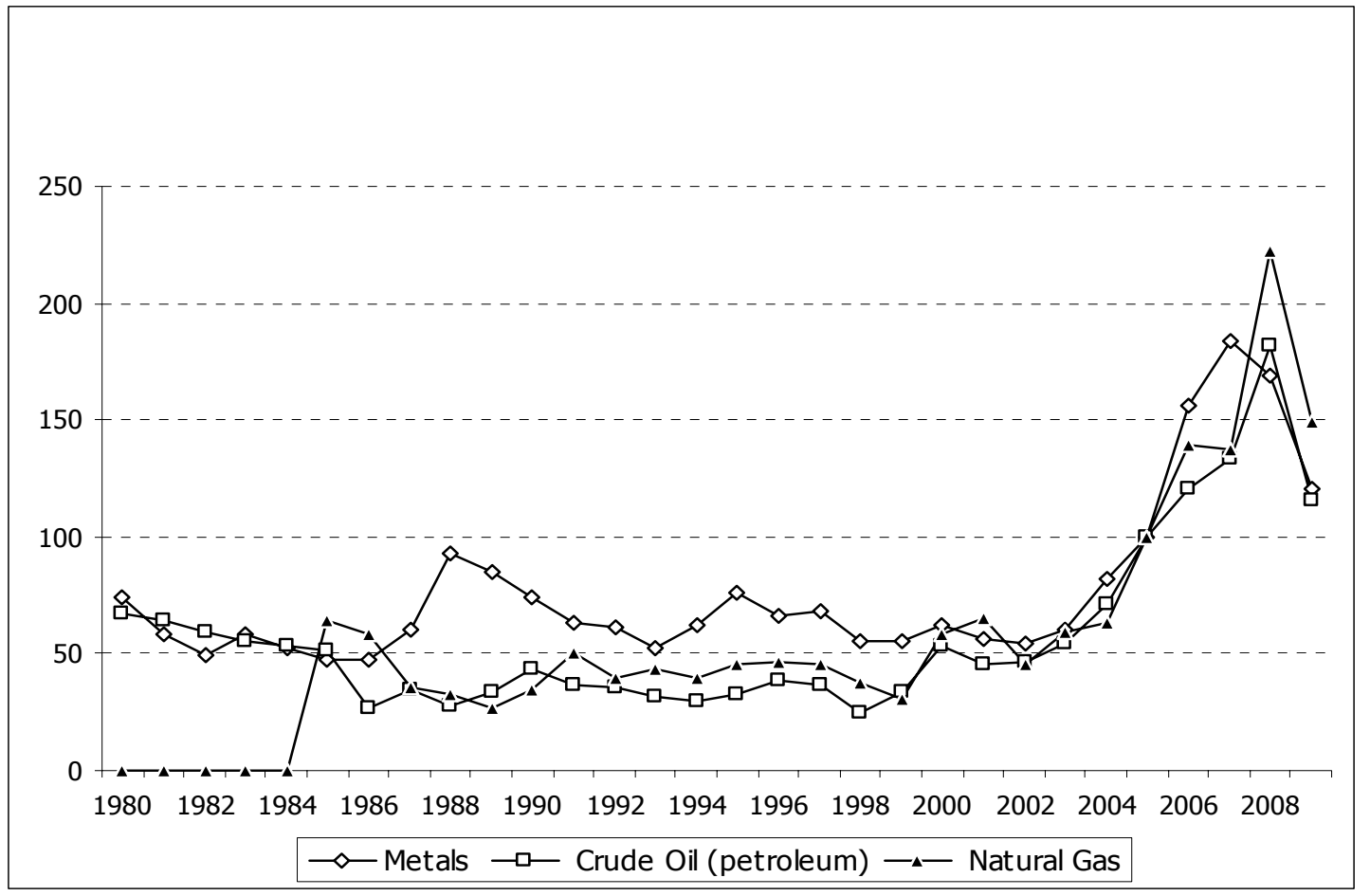

Attempts to increase national control over these external conditions and to reduce the profit outflow toward foreign shareholders, banks and downstream processing plants explain in part the history of nationalization in the mineral sectors. However, it is not possible to make simple generalizations regarding the relative success or failure of this history across developing countries. In the fuel sectors, there seems to be some tendency toward national (public) companies which, even if they are not able to influence significantly the external conditions of 
global markets, have been able to reduce the effects of external shocks in the domestic economies. The management capabilities developed in some of these public corporationssome with public-private partnerships-might be at the core of this achievement (UNCTAD 2007). State or national ownership would also have helped to address certain geopolitical concerns (as Jones Luong and Weinthal 2001 show in the post-Soviet states). In the mining sector, success through public ownership seems to be less common. The cases most cited in the literature are Botswana (for diamond production) and Chile (for copper production) (see Sachs and Warner 2001). In most other countries, even when they have undergone earlier experiences of nationalization, the period since the 1990s has seen a return to a more liberal orientation that favours private (and foreign) ownership. In that context, Shaxson (2005) argues that governments - with the assistance of third parties - could structure contracts with oil firms in such a way that some of the price volatility risks could be transferred to the private sector, without having to change either side's overall cumulative revenues.

It was - and still is - expected that the effect of public ownership on reducing the vulnerability of domestic economies to external shocks would also produce a similar effect on social welfare. Alternatively, if the industry is dominated by the private sector, it could be useful for governments to smooth earnings over international price cycles to avoid revenue volatility, which, in turn, hampers planning, boosts deficits and tends to raise debt, entailing an overall effect of reducing welfare in the long run. Both measures, however, require governments to be accountable in the use of mineral resources and revenues. In recession periods, they also require from the workforce a certain capacity to deal with the social costs of external shocks, so that public ownership is not a straitjacket for rejecting pro-competitiveness reform. In Bolivia, for example, Jordan and Warhurst (1992) describe how the mining union, in its struggle to protect the mining workers' interests, ultimately contributed to an increase in the instability of the whole economic system.

\section{Underinvestment and crowding-out effects on human capital}

Another possible effect of mineral dependence is the likely underinvestment in human capitalparticularly with regard to education-induced by an apparent lack of attention paid by governments to the need for a more educated population. This suggestion has been tested in the resource curse literature by comparing the rates of investment in education in resource-poor countries as opposed to the resource-rich, where the requirements for higher labour productivity in non-mineral sectors would be less compelling (Wade 1992). Gylfason (2001) provides evidence that, across countries, public expenditures on education relative to national income, expected years of schooling and school enrolment are all inversely related to natural resource dependence. Only few cases (clearly Botswana) would have used their mineral rents to increase investments in education-with a bias toward primary and secondary education (Gylfason 2008). The argument is, however, contested by other authors who highlight the difference between mineral abundance and mineral dependence. Indeed, in a recent contribution, Stijns (2006) disputes this suggestion, arguing that claims of a negative correlation between human capital accumulation and resource abundance are not robust, because of weaknesses in the measurement of natural resource abundance (as opposed to resource dependence). Through a more selective use of indicators, he found positive correlations among developing countries between subsoil wealth and human capital accumulation.

A related effect of mineral development on human capital has to do with poverty. Given that specific studies on the relationship between mineral resource abundance and poverty are few (World Bank 2002; Timmer 2004), much of the inference regarding the existence of a positive correlation between mineral dependence and poverty has been based on the indirect effects that other elements of the resource curse thesis (for example, conflicts or corruption) may have on producing or exacerbating poverty. In situations where social and armed conflicts are not present, and where public institutions are transparent and competent, the revenues generated by mineral sectors are-if well managed-expected to reduce poverty. The cases of Botswana, Chile, Indonesia and Malaysia are often cited as examples. 


\section{Implications of the resource curse political dimension for social policy}

\section{Conflicts}

The vast literature that identifies natural resource wealth as a major cause of conflict ${ }^{9}$ emerges $^{-}$ from an interpretation of the distortions introduced by large amounts of mineral rents and revenue into national and subnational economies. Collier's "finance for rebellion" model establishes that revenues from natural resources motivate looting, and provide an opportunity for financing large-scale violence (Collier and Hoeffler 2005). The "state-capacity" model (see Fearon and Laitin 2003) proposes that natural resource-dependent countries have a lower level of bureaucratic capacity because natural resource dependence leads states to become governors of rentier economies - that is, states that through access to external rent are liberated from the need to extract income from their domestic economy (Yates 1996) ${ }^{10}$-and also because dependency implicitly weakens states. Country cases often cited to illustrate the parallel evolution of mineral wealth extraction and conflicts are the Democratic Republic of the Congo (Carlson 2006) and Angola (Addison 2003). Nevertheless, De Soysa and Neumayer (2007) show that both models can be contested if a more accurate measurement of rents could be obtained. These authors argue that only in some cases might energy rents increase the risk of civil war, while mineral rents would not have any significant effect. Similarly, Ross (2004) points out that a positive relationship between natural resources and civil war cannot be generalized and that there are problems with the ways in which civil wars are coded. In a review of 14 crosssectional studies and a number of qualitative studies, he finds that oil increases the likelihood of conflict - in particular separatist conflicts - and "lootable" commodities like gemstones tend to lengthen existing conflicts. However, other natural resources do not show any significant correlation with internal wars.

Such a relationship between mineral wealth and political conflict is far from being unproblematic in its implications on social policy. First, one can intuitively assert that the revenues used for financing conflicts (both for attack and defence) withdraw resources from alternative, more productive or social policy use. Thus, when mineral wealth becomes the main source of government revenue, in addition to inducing conflict, it crowds out overall state governance capacity. Second, the role of democratic states in facilitating or impeding the emergence of conflicts is not clear. It has been argued that, in African contexts, democracy has enabled regional elites to fight over resource rents (for instance, in Nigeria). But a democratic regime may also reduce rent-seeking or, which would be positive, avoid regional conflicts via redistributive social policy.

A relatively new type of conflict observed in mining areas occurs between and among multinational corporations and a range of civil society and related organizations (mainly community groups, religious and human rights organizations, social movements and nongovernmental organizations/NGOs), with states playing a range of roles. ${ }^{11}$ These socioenvironmental conflicts involve competition over the rural territories and/or the nonmining resources involved (land and water), human and citizenship rights abuses, and/or dissatisfaction over the distribution of the revenues that mineral development is producing. Such conflicts may have been producing mixed effects on state revenue. They have exerted social pressure for governments to renegotiate contractual terms with corporations (for instance, in Bolivia the government increased the royalties rate in the gas sector) or to persuade corporations to enhance their contributions and/or lobby for greater fiscal transfers to mine-

\footnotetext{
9 See De Soysa and Neumayer (2007) and the references cited therein.

${ }^{10}$ Yates (1996) and previous contributors, such as Beblawi (1987), include the following characteristics to define a rentier state: rent predominance in the economy; the rent must come from outside the country; only the few are engaged in the generation of rent (as opposed to tourism, for instance), while the majority is involved in its distribution and consumption; and the government must be the principal recipient of the external rent in the economy. These authors highlight the external character of oil rents based on the foreign origin of investors and the foreign markets where mineral resources become valuable. Yates/Beblawi's definition of a rentier state is the standard in mineral resources/resource curse literature; it was coined specifically for oil-dependent countries and then expanded to other contexts where governments extract rents from a natural resource (as opposed to promote a more productive use of it, for instance, through processing).

11 Hinojosa and Bebbington 2010; Bebbington et al. 2007; Bebbington 2007.
} 
affected areas (as in the Peruvian case, where the sector rejected any increase in tax and royalty payments but offered "voluntary contributions" to local communities whose investment would be determined by the companies). However, in so far as the mitigation and solution of those conflicts involve the deployment of state financial and human resources (for example, via police mobilization or the establishment of coordination spaces and referendums to approve mining expansion), the utilization of state revenue may need to be diverted from some more productive spending and might eventually erode if conflicts evolve to the point that they stop mineral activity. That said, in many cases the companies may themselves make direct contributions to police and security forces. In the presence of so many variables and possibilities, the final implications of these conflicts for state revenues are yet to be assessed.

\section{Governance}

Perhaps the main concern about a negative relationship between good governance and mineral wealth relates to the lack of transparency and corruption in the appropriation and use of state revenue that characterizes many MDCs. Political corruption that capitalizes on allocating resources to favoured constituents, who, in turn, favour the politicians currently in power, has been well documented, particularly in the fuel sector and sub-Saharan African context (Karl and Cutler 2004; Shaxson 2007). The active involvement of the TNCs in creating and exacerbating violence against local populations has also been documented (as Pegg 1999 and Manby 1999 illustrate in the Nigerian context). It is argued that this vicious circle does not provide an incentive to governments to build up the institutional infrastructure needed to regulate and tax other non-mineral productive sectors in the economy. In addition, the surge or exacerbation of corruption due to the illicit appropriation of mineral rents would undermine the basis on which fiscal capacity rests, through heightening economic and social divisions and weakening institutional capacities in both states and economies (Isham et al. 2005; Dietsche 2008).

Although cases of bad governance are not confined only to mineral sectors or mineral-rich countries (Kumar 1991), the general consequence is that the implementation of sound economic policy that derives from and reinforces good governance is rarely observed among developing countries, particularly those that are highly dependent on oil exports (Karl 1997). Karl finds that pre-existing factors (institutional weaknesses, authoritarian regimes and so on) underlie this pattern, and their negative effects are exacerbated when oil rents fuel the development of rentier states. Statistical studies on African economies have found that natural resourcedependent economies, where the executive enjoyed discretionary power over mineral revenues without parliamentary control, were more likely to result in a breakdown in democratic governance and were also more often associated with authoritarian regimes, higher levels of spending and worse governance in general (Jensen and Wantchekon 2004).

The strong accent put on governance issues by international organizations, and increasingly also by corporations, reflects the prior pressure of civil society organizations around these issues. ${ }^{12}$ This convergence around governance shows that it might be possible to overcome the resource curse thesis. Having recognized that these issues - and the social mobilization around them - threaten the sustainability of large-scale investments, corporate policy has become more aware that measures are needed, not only to foster mineral sector growth but also to establish a more solid basis to ensure that this growth fosters development. The establishment of codes of conduct within the corporate sector (for instance, the commitment of Shell and BHP to nocorruption practices), the recognition that financial organizations can and should play a role on this (World Bank 2005), and the mounting efforts deployed by civil society organizations (national and international) to produce mechanisms that increase transparency, suggest the beginnings of a new route through which a more stable basis for revenue generation and its use in favour of national development might be achieved. Yet, making these mechanisms real and effective would require from MDCs' governments a good balance between securing energy sources for their developing economies and more accountability toward their citizens. In doing

\footnotetext{
${ }^{12}$ See, for instance the World Bank Extractive Industries Review, various reports of Oxfam America and Oxfam International, and recent initiatives of the International Council on Mining and Metals (ICMM).
} 
so, governments can overcome $\mathrm{TNCs}^{\prime}$ malpractices - in particular related to human rights abuses and environmental mismanagement-that usually happen in contexts where governance is weak and corporate social responsibility measures largely become a mechanism which, overall, protect the companies' interests (Pegg 2006a).

\section{Social welfare effects of transnational corporations in the mineral industry}

Part of the resource curse literature has emerged from the fact that the mineral industry is, by large, dominated by large-scale investments, whose linkages with other economic sectors - and indeed with local economies - are scanty. In addition, in cases where those investments come from foreign corporations, the allocation of "national" natural resources for private benefit has been questioned on the grounds that those investments would not have guaranteed fair returns to host countries' economies. Instead, as reviewed above, in cases like the sub-Saharan African oil industry, $\mathrm{TNCs}^{\prime}$ role in nurturing conflicts and oppression against local populations would have worsened indigenous peoples' vulnerabilities. That has directed attention to TNCs, particularly with regard to their effects on employment and their contribution to state revenue.

\section{TNCs and employment}

TNCs in the mineral sectors have produced mixed effects in the labour markets of host economies. The positive effects rely on the direct and indirect employment they have created and the corresponding sources of income that improve human welfare opportunities. Those effects, however, are differentiated by the labour market segments to which they are referred. At an overall level, the large scale, the capital intensiveness, and the finite period of time (determined by the mineral reserves) dictate the employment of a small skilled workforce that is usually well paid (Auty 2008). Yet the tendency of TNCs to use more capital-intensive technologies than domestic companies, and the improvements in general labour productivity that are derived from the TNCs' entrance into host countries, have reduced overall employment effects over time (UNCTAD 2007).

The concentration of high-skilled labour in the mineral sectors, to the detriment of other sectors in the economy, is one of the arguments used to suggest that a development strategy based on large-scale mineral projects generates exclusion, distorts the domestic labour market, and reduces opportunities for further development of other productive sectors. ${ }^{13}$ One could presume that, in cases where high-skilled labour is foreign, those effects are expected to be less severe and even to produce an opposite positive effect of "technology" transfer, as happened in other sectors (for instance in the Korean manufacturing development). However, there is not enough evidence to support that claim for the case of mineral production, an enclave sector with few linkages to the rest of the economy and few spillover effects within the sector itself.

The effects on the labour markets at a more local level are strongly dependent on the level of development of those markets. Although companies may declare some preference for hiring workers locally, given the skill requirements-often absent in the labour force of host localities - non-local workers and expatriates to take advantage of job opportunities opened up by new investments. This applies not just for the direct workforce employed by companies for their exploration and development activities, but also for indirect jobs through subcontractors. The ability of TNCs to promote the creation or strengthening of local enterprises via subcontracting (with expected effects on employment) is often restricted by local entrepreneurs' limited access to financial resources. This creates resentment among populations of host localities and also expands the wage gap in domestic labour markets. Some of the social protests observed in Andean countries against mining investments are an illustration of this effect (see Bebbington 2007).

Another source of negative effects on labour markets is the competition that can occur between large companies and small and artisanal miners in gaining access to mineral resources (as

${ }^{13}$ Gelb et al. 1988; Auty 1993; Neumayer 2004. 
Hilson and Yakovelva 2007 illustrate in a study on Ghana). Large mineral investments may also compete for the use of other ancillary resources (land and water), which reduces opportunities for agricultural development and strongly impacts employment levels in rural areasparticularly if it affects small-scale agriculture, which absorbs a large proportion of the labour force.

Last, but not least, are the effects on employment social benefits. First, TNCs in general comply with labour regulation and, in some cases, even go above established standards. Notwithstanding that practice can be positive per se and can induce a raise of social benefits, it also entails some negative externalities for domestic companies, which, in situations where the clause of equal treatment to foreign and domestic investments applies, are penalized because smaller companies do not have the resources needed for adopting higher labour standards. Second, regulatory restrictions in the labour market seems to have induced a trend toward subcontracting as a way of circumventing the direct legal requirements to which companies would otherwise have to adhere. This leads to a significant increase in the share of the local workforce that is outsourced, without any guarantee that the subcontractor will comply with labour regulation.

That said, there is not sufficient evidence to suggest that negative employment effects are exclusive to TNCs, nor that state-owned companies guarantee better working conditions than private (domestic or transnational) companies.

\section{TNCs and state revenue}

It is generally assumed that the principal benefit to host countries of TNC involvement in extractive industries is the generation of fiscal revenue. This justifies the continuous attempts made by host governments to attract FDI, as well as international organizations' efforts to ease financial and institutional conditions in order to facilitate such investments.

In general terms, the financial contributions that large-scale foreign investment brings into host economies are related to their ability to produce foreign exchange by enhancing exports and increasing capital inflows (UNCTAD 2007). TNCs can also overcome financial constraints on national governments or domestic companies to develop the mineral sectors (as happened in periods after crisis or cases of failed nationalization in Latin America: ECLAC 2002). However, TNCs' profits flow back into the economies in which the ownership of capital resides (that is, wherever the main shareholders and banks are localized). Occasionally, TNCs have engaged in large-scale projects based on partnerships both with domestic private and public companies.

There might be a trade-off between MDCs' goal to attract FDI by providing fiscal incentives (such as favourable tax regimes or subsidies) toward potential investors and the government's objective to maximize tax revenues from the mineral sector. Competition for mobile global capital tends to reduce governments' capacities to negotiate favourable terms and conditions for the host country. If, in addition, host governments are characterized by a high rate of political instability and short-term governments and a lack of transparency and corruption (as Clark and Naito 1997 noted in the case of Eastern European MDCs), negotiations between government and foreign companies become extremely difficult and entail a potential risk of substantial conflict between the expectations and goals of governments-and population-and those of industry.

In those conditions, the negotiation capabilities of corporations and governments vary during the course of the long-run relationships that these investments imply. Although at the initial stages corporations have advantages - in terms of technical information from the mine feasibility studies and the ability to assemble finance, technology, skills and market accessafter investing, their bargaining strength usually weakens vis-à-vis the host government (Auty 2008). Similarly, at the initial stages governments concede particularly favourable conditions to TNCs (for example, tax and royalty "holidays" that allow the companies to recoup their large 
sunk capital and to earn the target rate of return). However, renegotiation processes occur over the exploitation phase-in the extreme case, a return to nationalization (for example, in Bolivia) - in an attempt to regain some control over the revenue that the sector produces. Cases where a third party intervenes (such as the World Bank in the Chad-Cameroon Oil Pipeline Project; Gould and Winters 2007) are no exception; contracts may become "obsolete" in the eyes of host governments - and groups of civil society - who reclaim a fairer distribution.

The entanglement of government-companies' negotiations and the reactions it has produced in civil society organizations (both locally and globally) has brought into debate the constraints inherent in a weak state, in those MDCs whose institutional apparatuses restrain the design of fiscal regimes more oriented to benefit national interests. That debate also points to the fact that an investor-friendly fiscal regime for the mineral sector may undermine states' capacity to negotiate tax arrangements with their own citizens. Furthermore, in the recent economic crisis where global market conditions have changed radically, the necessity for institutional change becomes an imperative, should the state be more accountable to national interests. ${ }^{14}$

\section{What We Know about the Relationship between Mineral Wealth and Social Policy}

The preceding section presents a rather pessimistic view of extractive industries as a significant source of growth and development. Yet the hope for a positive relationship is ever-present in the discourse of many political actors, such as MDC governments and international organizations, and in the reflection of several scholars. This section analyses the relationships between mineral wealth and the state's ability to capture revenue and use it for social services. Three sets of connected assumptions are tested: (i) the extent to which dependence on mineral exports affects the level of state revenue; (ii) the connection between mineral wealth and social policy; and (iii) the institutional conditions under which mineral wealth can improve social welfare.

Methodologically, we introduce a variation to cross-country studies which compare mineral to non-mineral economies - and incidentally, developed to less-developed countries-and we discuss a particular pattern of social policy in MDCs. Quantitative data come from the World Bank, the IMF, UNCTAD and the World Health Organization (WHO) databases. ${ }^{15}$ Whenever possible, averages for the period 1995-2005 were calculated, otherwise averages are for the closest period of available data. We chose that period to include years when mineral production and revenue were relatively stable (1995-2003) and two more years (2004-2005) when both increased, due to rising oil and mineral prices, but had not reached the maximum level. Qualitative data come from authors' research. It was also difficult to obtain data for the period before 1995 and after 2005, in particular for government spending.

Assumption 1: In MDCs, dependence on mineral exports affects the level of state revenue derived from mineral sectors.

This assumption is tested by looking at the association between several categories of state revenue and mineral wealth measured by the ratio of mineral exports to GDP. Although some of the mineral production is also oriented to domestic markets, the justification for this proxy is that it is the conventional measure of economic dependence on mineral commodities in the development literature, as shown above. Revenue (excluding grants) is taken as a percentage of GDP in order to observe the government's capacity to mobilize resources in the domestic economy. In mineral-rich countries, much of these resources are expected to come from mineral sectors.

\footnotetext{
${ }^{14}$ See the "The 'Pay your Taxes' Debate" in Chile (Riesco et al. 2005) for a country-specific analysis, and Dietsche (2008) for an overall reflection on these points.

${ }^{15}$ Databases available, with restricted access, at ESDS International, Mimas, University of Manchester.
} 
Given the lack of sectoral data which constrains a more accurate assessment of the fiscal effects produced by companies and wage labour in the mineral sectors, the categories of state revenue included here are general taxes as an overall effect, and taxes on income profits and capital gains (TIPKG) and social contributions (SC), which capture most of the sector's fiscal contributions. Revenue is taken as a percentage of GDP, TIPKG as a percentage of total taxes and SC as a percentage of total revenue, in order to keep implicit the contribution of other sectors (or taxpayers) to the fiscal coffer.

Results of ordinary least square regressions are shown in table 1.

Table 1: Association between state revenue and mineral export dependence (estimates based on averages for 1995-2005)

\begin{tabular}{|c|c|c|c|c|}
\hline & $\log R \% G D P^{a}$ & $\log T R \% R^{b}$ & $\begin{array}{c}\text { Log TIPKG' } \\
\text { (\% taxes) }\end{array}$ & $\log \mathrm{SC}(\% R)^{\mathrm{d}}$ \\
\hline $\begin{array}{l}\text { Log ratio metals and } \\
\text { ores exports: total } \\
\text { exports }\end{array}$ & $\begin{array}{c}-0.095 \\
(-1.989)^{\mathrm{e}}\end{array}$ & $\begin{array}{l}-0.045 \\
(-0.943)\end{array}$ & $\begin{array}{l}-0.020 \\
(-0.303)\end{array}$ & $\begin{array}{l}-0.075 \\
(-0.400)\end{array}$ \\
\hline $\begin{array}{l}\text { Log ratio fuels } \\
\text { exports: total exports }\end{array}$ & $\begin{array}{c}-0.080 \\
(-1.670)^{\mathrm{e}}\end{array}$ & $\begin{array}{c}-0.082 \\
(-1.719)^{\mathrm{e}}\end{array}$ & $\begin{array}{c}0.034 \\
(0.506)\end{array}$ & $\begin{array}{c}0.182 \\
(0.993)\end{array}$ \\
\hline Constant & $\begin{array}{c}3.389 \\
(18.753)^{\mathrm{e}}\end{array}$ & $\begin{array}{c}2.914 \\
(16.315)^{\mathrm{e}}\end{array}$ & $\begin{array}{c}3.227 \\
(12.647)^{\mathrm{e}}\end{array}$ & $\begin{array}{c}1.838 \\
(2.662)^{\mathrm{e}}\end{array}$ \\
\hline R2 & 0.075 & 0.055 & 0.018 & 0.059 \\
\hline $\mathrm{N}-\mathrm{K}$ & 52 & 52 & 52 & 35 \\
\hline
\end{tabular}

Notes: T-ratios appear in parentheses. ${ }^{a} \mathrm{R} \% \mathrm{GDP}=$ Revenue (excluding grants) as a percentage of GDP. ${ }^{\mathrm{b}} \mathrm{TR} \% \mathrm{R}=\mathrm{general}$ taxes as a percentage of revenue? ${ }^{\mathrm{c}}$ TIPKG $=$ taxes on income profits, and capital gains. ${ }^{\mathrm{d}} \mathrm{SC}=$ social contributions as a percentage of revenue? e Correlation is significant at the 0.05 level.

Although this first set of regressions can be taken as exploratory, due to the regression curves' low fit, the negative association found is revealing. Fuel-dependent countries show stronger negative correlation between revenue, tax revenue and mineral dependence. In miningdependent countries, a negative association is significant only with regard to total revenue. This-at least-should call into question the simplistic discourse that increased mineral exploitation will be translated into significant earnings for the whole economy and an equivalent increase of state revenue.

A straightforward question is about the causes of such a disassociation. The literature on mineral resources and state revenue has widely documented that governments in mineral-rich countries obtain fiscal benefits from mineral exploitation, especially in the long term, based on their taxation method. It also acknowledges that there are effective trade-offs between encouraging investment and reaping substantial government revenues (Garnaut and CluniesRoss 1983). The question that remains open is, then, whether the taxation methods implemented in mineral-dependent economies - and the multiple fiscal instruments that give preferential treatment to corporations (tax depreciation, tax incentives, allowable tax deductions for costs, foreign re-investment allowance, and the like: see Sarma and Naresh 2001 for illustrations) - do extract sufficient revenues from production and profits, as O'Faircheallaigh (1998) suggests, to compensate local communities for the use of their resources.

The criticism made of mineral companies - and of governments for being weak negotiators - is rooted in the perception that taxing mineral production has not mobilized sufficient revenues to ensure long-term economic benefits for host countries - and perhaps not even enough to offset the social and environmental costs involved in such a development strategy. ${ }^{16}$ Dealing with critics, MDC governments have voiced concerns that excessive taxation will repel investors and, hence, have implicitly suggested that an eventual trade-off between state revenues and other

\footnotetext{
${ }^{16}$ A criticism raised by many civil society organizations (see, for instance, the Mines and Communities network website, www.minesandcommunities.org).
} 
benefits of mineral development (which would basically bring in foreign exchange) is acceptable. The next subsection looks at taxation issues.

\section{Taxes and royalties}

If there is a trade-off between maximizing revenue from taxation and maximizing profits for the investors (Otto 2000), the taxation system is a domain of negotiation that has to do justice to both objectives. Defining an optimal tax system for the mineral sector is therefore far from being a technical issue to be confined to government tax agencies (Davis 2007). On the contrary, the design and implementation of taxation systems requires some sort of macroeconomic governance perspective wherein the responsibilities of state, market and civil society actors are complementary (Goolsbee 2004; Matshediso 2005). It also requires an institutional setting that facilitates the design and implementation of fiscal regimes, which redirects the accountability of the state toward its citizens and produces a social contract (Dietsche 2008).

Although a detailed assessment of taxation systems in MDCs goes beyond the scope of this paper, two points deserve attention. Even though most MDCs combine different taxation methods, including corporate taxes and royalties, there is no ideal one-size tax system. Therefore, as others have suggested, "the national tax policy for the mineral sector accommodates unique needs and capacities" (Otto et al. 2007:18). However, increased competition, regional integration and transnationalization in the extractive industries (Bebbington and Hinojosa 2007) have also, over time, induced an increased implicit harmonization of basic taxation in a way that reduces competition between countries - more often in "a race to the bottom", so as to attract foreign investment.

The second point relates to the connection between taxation systems and social policy regimes. There is no particular relationship between the low-tax regime of an economy aiming at attracting investors, and the welfare outcomes it may be able to generate. States can choose to mobilize revenue from other economic sectors and production factors (such as labour) which in turn can be invested in social policies, or they can opt to establish social systems which are market-based and financed through contributions to private insurance and out-of-pocket payments for services. Chile is a good example for the latter model: while the country is characterized by relatively low tax rates in the copper sector, it has been able to develop a comprehensive welfare system through mandated market insurance such as private pension funds. Other MDCs could achieve similar welfare outcomes based on different systems of financing and provisioning, therefore they would be less reliant on high taxes on mining investments. However, the opportunity costs of foregone state revenue grow in countries with less capacity to mobilize alternative revenues and where private insurance is limited. But, even in successful cases of mineral development, there are concerns about the uneven distribution of mineral revenue between host countries and foreign investors. For instance, Chile was revisiting its no-royalties policy (Otto et al. 2007) after strong debates on the inadequacy of its mining tax regime (Riesco et al. 2005). Additionally, there is also evidence that the social policies implemented in a context of significant economic growth have not been enough to counteract the costs in terms of adverse environmental and social impacts associated with mineral development (see Meller et al. 1996 on Chile).

Conversely, insecurity regimes can also be observed in countries with either higher or lower taxation rates. Almost by definition, a simple regression between levels of state revenue and taxes would show the inextricable linkage between these two variables, but the evidence is less conclusive about tax systems (rates and modalities included) and state revenue. Furthermore, it does not say much about the likely implications in terms of social policy. This is explored below.

Assumption 2: In mineral-dependent economies, the linkage between mineral wealth and social policy occurs in four dimensions: 
2.1 mineral wealth encourages higher levels of social expenditure;

2.2 mineral wealth produces fiscal space for social policy;

2.3 mineral wealth influences the composition of social expenditure;

2.4 mineral wealth enables the initiation of new social policy initiatives.

Given the scope of these assumptions, and the limited data available in most MDCs, the four parts of assumption 2 are tested in an exploratory way through correlation and cluster analysis, and illustrated with examples. Unless noted differently, estimates are based on averages for the period 1995-2005. For correlation analysis, health expenditure per capita is taken as a proxy for the state's capacity to respond to the health care demand of its entire population. Expenditures on health and education, as a percentage of GDP, implicitly include the proposition that changes in the ratio expenditure to GDP reveal an effect on revenue distribution. ${ }^{17}$ The main findings of this analysis indicate that state revenues and expenditure in social sectors are positively related, that there is a certain geographical pattern in the conformation of welfare regimes and, indeed, that mineral wealth reinforces such a pattern. This pattern was explored further through cluster analysis and, as reported below, ${ }^{18}$ mineral-dependent African countries seem to be locked in insecurity regimes while Latin American and East-European countries show concentration around informal security regimes.

The results of non-parametric ${ }^{19}$ correlation are presented in table 2.

Table 2: State expenditure and revenue in mineral-rich developing countries

\begin{tabular}{|c|c|c|c|c|}
\hline & $\begin{array}{c}\text { Health } \\
\text { expenditure per } \\
\text { capita (current } \$ \text { ) }\end{array}$ & $\begin{array}{c}\text { Health } \\
\text { expenditure, } \\
\text { public (\% of } G D P \text { ) }\end{array}$ & $\begin{array}{c}\text { Health } \\
\text { expenditure, total } \\
\text { (\% of GDP) }\end{array}$ & $\begin{array}{c}\text { Public spending on } \\
\text { education, total } \\
\text { (\% of GDP) }\end{array}$ \\
\hline $\begin{array}{l}\text { Revenue, excluding } \\
\text { grants ( } \% \text { of GDP) }\end{array}$ & $0.624^{\mathrm{a}}$ & $0.743^{a}$ & $0.477^{\mathrm{a}}$ & $0.691^{a}$ \\
\hline $\begin{array}{l}\text { Tax revenue (\% of } \\
\text { GDP) }\end{array}$ & $0.357^{\mathrm{a}}$ & $0.542^{\mathrm{a}}$ & $0.374^{\mathrm{a}}$ & $0.549^{a}$ \\
\hline $\begin{array}{l}\text { Social contributions } \\
\text { ( } \% \text { of revenue) }\end{array}$ & 0.287 & $0.330^{\mathrm{b}}$ & 0.239 & -0.025 \\
\hline $\begin{array}{l}\text { Taxes on income, } \\
\text { profits and capital } \\
\text { gains ( } \% \text { of revenue) }\end{array}$ & 0.07 & -0.161 & $-0.297^{b}$ & 0.18 \\
\hline $\begin{array}{l}\text { Taxes on income, } \\
\text { profits and capital } \\
\text { gains (\% of total } \\
\text { taxes) }\end{array}$ & 0.203 & -0.063 & -0.256 & $0.304^{b}$ \\
\hline
\end{tabular}

Notes: Cells contain Spearman's Rho correlations. ${ }^{\mathbf{a}}$ Correlation is significant at the 0.01 level. ${ }^{\mathbf{b}}$ Correlation is significant at the 0.05 level.

As expected, the association between revenue and expenditure in social sectors is revealed in each instance to be positive and significant. Similar results are reported for tax revenue. The correlation of social contributions (as a percentage of total revenue) and public expenditure in the health sector is positive, but negative in the case of public education. ${ }^{20}$ If the association between government revenue and mineral export dependence is negative (as shown in table 1), then the mixed results for the association between negative correlations between taxes on income, profits and capital gains (the proxy used to observe the direct contribution of mineral sectors) and expenditure in social sectors (negative in the case of health and positive in education) would suggest that the higher the mineral dependence, the lower the revenue that is

\footnotetext{
${ }^{17}$ In so far as revenue and tax revenue are both a percentage of GDP, correlation coefficients would not change if absolute values were instead used for calculations.

18 Outcome tables from cluster analysis are not included in this paper.

19 The Spearman's rank correlation coefficient is computed by using rank scores. For each of the variables $X$ and $Y$ separately, the observations are sorted into ascending order and replaced by their ranks. The advantage of this type of correlation is that it works regardless of the distributions of the variables and also reduces the effect of outliers.

${ }^{20}$ Although the negative association is not statistically significant in this case, it continues to be negative and becomes significant when public spending on education is measured as a percentage of government expenditure.
} 
captured by governments and, hence, the lower the amounts allocated for expenditure in social sectors. The evidence is less conclusive in regard to allocation of mineral tax resources among sectors, even though it seems to favour the education sector.

Some explanation of these results can be found in the social policy literature, which discusses the budget allocation based on the nature of the government (authoritarian or democratic) and also takes note of the role of civil society in protecting social spending, particularly in education. ${ }^{21}$ In that sense - taking into consideration the hypotheses that governments in MDCs would use the additional mineral budgetary resources in those sectors (and places) where there is more political pressure, and that a significant part of that spending would go to current spending (basically wages) - it can also be suggested that ultimately, the effect of mineral resources on the composition of social expenditure depends on the balance between social forces (for instance, between sectoral labour unions in Latin America, or some more regionbased movements in Africa).

To examine the effects of mineral wealth on welfare regimes (parts 2.2 and 2.4 of assumption 2), we explore how it impacts the levels and the composition of social expenditure in order to assess the effects, if any, of mineral wealth on the welfare mix (that is, the division of labour between public and private provision). Following the path traced by Powell and Barrientos (2004) and Gough et al. (2004) in their cluster analyses of welfare regimes, we use detailed data from WHO to construct MDC welfare regime clusters. The point of departure for cluster analysis is the presumption that countries are aggregated based on their welfare mix, approximated by the composition of health expenditure. ${ }^{22}$ Five variables are chosen to picture the welfare mix, each one indicating the role assumed by institutional actors in the provision of health - that is, the state (whose predominance defines a welfare state regime), the market (stressing the role of the private sector in an informal security regime) and international organizations (whose interventions are typically found in insecurity regimes). The variables are: the shares in total expenditure on health of general government expenditure; and the shares in total expenditure on health of private expenditure; external resources for health as a percentage of general government expenditure on health; social security spending on health as share in general government expenditure on health; and the out-of-pocket expenditure share in total expenditure on health.

The comparison of clusters of MDCs based on their expenditure levels, before and after adding the effect of mineral wealth (measured by the ratio of mineral exports to total exports), shows that mineral wealth reinforces the regional patterns of welfare regimes found by Gough et al. (2004) for selected groups of countries. Furthermore, patterns become clearer. For instance, differences between East European and African countries are more evident, most mineraldependent Latin American countries are clustered in an informal security regime, and the insecurity regime is dominant in groups of sub-Saharan countries.

\section{Social policy initiatives in MDCs}

The evidence presented above supports the general conclusion that the positive association between revenue and expenditure is indicative of the state's disposition to use its fiscal resources in social expenditure. However, it does not say anything about the kinds of expenditure involved in each case or the welfare outcomes actually achieved. For instance, revenue and expenditures can go up in a period of mineral boom, but how they are distributed remains an open question: they may be allocated progressively or regressively, may be targeted to particular groups or support universal coverage. Conversely, they can also be used to feed wages and bureaucracy under any type of social policy scheme without much effect on welfare.

\footnotetext{
${ }^{21}$ See UNRISD's contributions in this area (UNRISD 2006:6).

22 The selection of health as a variable to reveal the welfare mix meets two considerations: conceptually, health is one of the milestone variables for measuring social welfare and well-being and, as such, it is one of the main targets of social policy; and empirically, health is the only variable for which data is split by sector of provision (public or private).
} 
Given that possibility, we analysed the characteristics (type, coverage levels and other salient features) of social insurance and social assistance programmes in 56 MDCs operating in March 2008 (see annex). The analysis points to four aspects that are worth noting.

First, social insurance and social assistance programmes occur in almost all MDCs, regardless of their level of mineral export dependence. Similar programmes can be found in highly dependent economies (such as Botswana or Zambia) and in those less dependent (such as Namibia or South Africa). Nor are their coverage levels closely associated with the mineral basis of their export sectors. A positive relationship between mineral dependence and social protection seems to be more likely in countries where state capacity guarantees a good use of mineral revenue, as has happened in Chile through new social assistance programmes and the strengthening of redistribution since the return of democratic rule in 1990. In this respect, the way mineral revenue is managed in the long term becomes important in order to guarantee financial and institutional sustainability of social programmes.

Second, social insurance systems are more popular in countries which have a certain state-led social policy tradition (for instance, the Eastern European MDCs such as Lithuania and the Russian Federation, and Kyrgyzstan and Tajikistan in Central Asia: see annex); however, there is not much relation between the level of dependence and social security coverage. In those countries, social insurance can be affected by the swings in revenue introduced by price cycles.

Third, social assistance programmes are also common to many MDCs, and their introduction seems to have responded more to a social agenda (Willmore 2007) than to mineral revenue availability. In some cases, for example, Bolivia and Nigeria, an additional inflow of revenue (whether from the mineral sectors as in Nigeria or from privatization revenues in the 1990s and more recently, from re-nationalization and new taxes levied on the hydrocarbon industry as in Bolivia) has helped the implementation of the respective government's social programmes. However, if these programmes are financed with taxes and mineral revenue (as in Chile: Guajardo 2008), their financial sustainability depends on the government's ability to keep a stable fiscal coffer, even during downturn periods or when further possibilities of mineral extraction decline.

Fourth, in the long term and considering the enclave character of many mineral economies, it is worth recalling that links between the financial resources produced in mineral sectors and the development of domestic financial markets can be enhanced in the same way that the linkages between mineral sectors and the rest of the productive sectors can be improved. Mineral revenues can be invested in domestic financial and capital markets, and they serve as long-term investment instruments for institutional investors such as pension funds, as can be seen in Argentina (before the private pension system was renationalized in 2008) and Chile.

A final reflection regards the influence of mineral wealth on the composition of social expenditure and the extent to which it may influence the trajectory of new social policy initiatives. In the context of the expansion of extractive industries, the organized reaction of civil society groups and companies' responses have changed the way in which social services are provisioned and delivered (that is, the composition of a welfare mix discussed in the introduction). Adésínà (2008) documents how, in the 1970s, regional groups put the Nigerian government under pressure to launch the universal primary education programme and a range of other social investments by using mineral-based national resources. Yet Nigeria from the 1990s also illustrates clientelism between local elites, state governors and the oil companies (Meagher 2007, quoted in Adésínà 2008). In Equatorial Guinea (at the time of writing), the international community present in the country was persuading the government to extend the social protection programmes-partially financed by oil revenue-to cover the poorest population and not just formal workers. In Andean MDCs, Bebbington and Hinojosa (2007) suggest that civil society organizations have shaped the social responsibilities adopted by corporations in the mining sector, and Bebbington and Burneo (2008) argue that they have also influenced the Peruvian government's position regarding the relationship and trade-offs 
between mineral investment and people's rights. Similar influences have been observed on companies' behaviour in Eastern and Southeastern Asian MDCs, with the possible caveat that civil society pressure has had less effect on government. ${ }^{23}$ On the other hand, the corporate sector has declared its commitment to making the mineral sector "a key contributor to sustainable development", and implemented corporate social responsibility (CSR) measures and/or followed other initiatives for good governance at national and global levels, by means of private action. ${ }^{24}$ However, in many cases CSR experiences have been highly criticized (Frynas 2005; Pegg 2006b) as being high in rhetoric and low in effectiveness. Despite all criticism, companies, civil society and citizens alike acknowledge that, to make CSR effective, an accountable and high-quality public sector is essential. This point is taken up in assumption 3.

Assumption 3: In MDCs, the quality of government affects the extent to which the state can capture revenue and spend it in social policy.

The first part of this assumption is tested by regression analysis of state revenues and measures of institutional and policy quality. The second part is addressed by looking at the relationships between expenditure and government quality. The proxy used to measure both institutional and policy quality is the country policy and institutional assessment (CPIA) estimated by the World Bank. ${ }^{25}$ In this latter case, given that data does not support regression analysis, we report only correlation coefficients to approximate signs of association.

The results reported in table 3 indicate that revenue and tax revenue are positively associated with the quality of public sector management (at all levels) and the institutions which enable governments to capture revenue from all economic sectors. However, institutional state capacity would not necessarily imply a better capacity to increase the share of tax on income profits and capital gains (which significantly includes the corporate mineral sector in the more mineral-dependent countries).

The association between institutions and economic performance has been explored on diverse grounds, and this has constituted an ever-more important component and contribution of the resource curse literature, with commentators tending to agree that mineral wealth has generally harmed the quality of governance structures (see section 2). On a similar note, Dietsche (2008) concludes that what hinders MDCs from building capacity and improving the quality of institutions is the way in which fiscal regimes have been designed in the absence of state capacity and good institutions. However, those conclusions are also matter of debate. For instance, Isham et al. (2005) show that, in a sample of 45 mineral export countries, institutional quality indicators tend to be poor, particularly with regard to rule of law, political stability, government effectiveness and corruption. Yet, those countries are not very different from nonmineral countries when measured on indicators such as law and order tradition, quality of bureaucracy, political rights, civil liberties and property rights, and rule-based governance. The robustness of econometric studies which try to measure institutional and political factors has also been criticized (see, for example, Rosser 2006). In a more recent piece, Rosser (2009) also suggests that the institutional change needed to overcome the resource curse requires farreaching political and social change, which implies a further effort to understand the causes of and conditions for that change.

\footnotetext{
${ }^{23}$ That was one of the main conclusions of the international conference on large-scale mining, Reframing the Debate, held in Manila in November 2007.

${ }^{24}$ See, for instance, ICMM's website (www.icmm.com).

25 The CPIA assesses the quality of a country's policy and institutional framework (that is, the extent to which that framework supports sustainable growth, poverty reduction and the effective use of development assistance: World Bank 2006:4). Given the methodology used for its estimation, we find it useful for studies regarding social development and preferable to alternative indicators of institutional quality which are more focused on the effects of institutions on investments.
} 
Table 3: Association between state revenue and institutional quality in MDCs

\begin{tabular}{lccc}
\hline & $\begin{array}{c}\text { Log revenue excluding } \\
\text { grants }(\% \text { GDP) }\end{array}$ & Log tax (\% revenue) & $\begin{array}{c}\text { Log tax income profits } \\
\text { capital gains (\% taxes) }\end{array}$ \\
\hline $\begin{array}{l}\text { Log CPIA public sector } \\
\text { management and }\end{array}$ & 0.634 & 1.564 & -1.158 \\
institutions cluster average & $(2.004)^{\mathrm{a}}$ & $(1.993)^{\mathrm{a}}$ & $(1.076)^{\mathrm{a}}$ \\
Log CPIA transparency, & & & \\
accountability, and & -0.196 & -0.553 & 0.002 \\
corruption in the public & $(-0.621)$ & $(-0.829)$ & $(0.403)$ \\
sector rating & 1.367 & & 3.079 \\
Constant & $(2.438)^{\mathrm{a}}$ & 1.367 & $(20.280)^{\mathrm{a}}$ \\
R2 & 0.239 & $(2.660)^{\mathrm{a}}$ & 0.036 \\
$\mathrm{~N}-\mathrm{K}$ & 22 & 0.207 & 22 \\
\hline
\end{tabular}

Notes: T-ratios appear in parentheses. ${ }^{a}$ Correlation is significant at the 0.05 level.

A major concern about the relationship between institutional quality and mineral revenue inflows regards sequencing. ${ }^{26}$ Successful cases of mineral revenue management (for example, Botswana, Chile and Norway) seem to be associated with initial good institutional quality often built up before the revenues from the resources start to come in. Conversely, mineral resources come to a country where the institutional quality is poor, the effect seems to be the exacerbation of existing problems and the start of new ones (as the Chad-Cameroon oil pipeline project illustrates well-see Gould and Winters 2007). Therefore, democratic governance and state capacity building are all-important, as is the understanding of the need to build supporting coalitions for positive social welfare outcomes.

Our findings, and the multiple contributions on institutional matters reviewed above, lead us to conclude that, while some MDCs are partially prepared to take advantage of mineral development, others require careful consideration before large mineral projects are implemented. In the former case, what may be needed for escaping the resource curse (in the institutional sense) is to improve the conditions for institutional and policy standards in time for the mineral revenue (see also Lewis 2007; Smith 2007). That implies enhancing mechanisms to improve the functioning of governments and opening the space for good governance. In the latter-where institutional quality is poor-it is important to implement structural change in the state apparatus before the resource revenue starts to come in. That requires further understanding of the ways in which mineral development produces incentives, alliances and conflicts that influence the trajectories of state formation, and, hence, greater attention to its impact on governance.

Our accent on the governance arrangements that mineral development produces is oriented toward understanding how a mineral-led development strategy affects the composition of a welfare mix - that is, the extent to which mineral wealth facilitates the role of the state to develop a welfare state regime or, instead, reinforces the mechanisms characterizing informal security regime, or even increases the risks of falling in or perpetuating an insecurity regime. The next section elaborates on this.

\section{Toward an Integrative Approach for Understanding the Linkages between State Revenue and Social Policy in Mineral-Wealth Contexts}

With the caution that the reader might do well to maintain a critical view of the strengths and caveats of cross-sectional studies, our findings on the relationships between social policies, state revenue, social welfare and mineral wealth suggest that there is not enough evidence to support

${ }^{26}$ This topic was raised by one of our anonymous referees. 
any simplistic argument about a deterministic relation between mineral dependence, social policy and social welfare. Therefore, in order to understand the influences of mineral wealth on social policy, we propose an integrative approach.

Our approach is informed by the general principles on welfare regimes outlined by EspingAndersen $(1990,1999)$ and applied to developing countries by Gough et al. (2004). On that base, it expands in two directions:

(i) We agree with the idea of characterizing a dominant regime (for example, welfare state regime, informal security regime and insecurity regime; see also the introduction) as a way to simplify the complex reality of social welfare provision. ${ }^{27}$ However, our interest is in the process of change of the welfare mix - that is, the change due to the effects of mineral wealth in the division of labour between state, markets and households in social provision, and the political, economic and social arrangements that underlie a welfare regime. For this, we suggest that in some MDCs the balance of state, market and informal social provisioning is changing, while in others current patterns are reinforced. The effect of mineral wealth on social welfare can be perceived precisely through its effect on these processes. For instance, Bolivia, classified as an informal security regime, seems to be moving toward a stronger role of the state in social provision - at least in the political discourse and the recent social policies implemented for securing free primary education and cash transfers (including a universal social pension). On the contrary, mineral production can also lead to a weakening of the existing welfare regime. For instance, in the absence of regulatory policies to prevent the negative environmental effects of extractive industries on vulnerable people, the environmental impact of pollution and biodiversity loss may undermine the basis for an informal security regime. ${ }^{28}$ Chile illustrates a case where, given its tradition on social welfare provision, the revenue derived from its mineral wealth has been used to reinforce public social policies, in particular after the change of political regime from dictatorship to democratic governance.

(ii) Even though social policy might provide entitlements as a matter of citizenship and rights, we suggest that the opportunities and struggles produced by the expansion of extractive industries in MDCs shape both the composition of the welfare mix and the mechanisms of social policy delivery.

Based on the evidence provided in previous sections about the effects of mineral revenue on the strengthening or weakening of a welfare state regime and the likely effects on the informal security and insecurity regimes, we identify the following constitutive elements of an approach to track linkages between mineral wealth and social welfare.

First, the departure point is that, wherever the tax system enables a country to capture most of the mineral revenue, the revenue opens up fiscal space for a range of social policy measures. These include an extension of existing programmes, new initiatives or both.

Second, given that welfare regimes and their social outcomes depend on the country's economic, political and social structures and institutions, and mineral revenue affects each one of these structures, the eventual effect of mineral wealth on social welfare is indirect. Therefore, mineral wealth can be a curse or a blessing - in social welfare terms - depending on its impact on processes of change within and between welfare regimes.

\footnotetext{
27 This argument was raised by Wood and Gough (2006:1700). While theoretically adopting a "dominant regime" approach, they also admit that, in reality, hybrid regimes can be observed (for instance, some people may be seen to be in a welfare state regime, while others could be in an informal security regime or an externally dependent insecurity regime). We acknowledge comments on this point from Anthony Hall and Tanja Muller from their research in developing countries.

${ }^{28}$ See Development Solutions et al. (2009) for an approximation to this issue in Andean countries[0].
} 
Third, mineral wealth adds new factors that influence the composition of a welfare mix (for example, the country's history, its social policy tradition and developmental strategy, its level of international insertion/dependence, and so on). These are:

(i) of a macroeconomic nature - mineral wealth creates fiscal space for social welfare provision; it reduces possibilities for sector diversification; and it introduces external dependence, which produces fiscal vulnerability. Growth is hindered by excessive reliance on primary production in exhaustible mineral sectors, whether by reducing opportunities for transferring labour from low-skill-intensive mining to more lucrative jobs in more high-skill-intensive occupations, or by reducing the tax base. A low tax base arises from the usually informal nature of small-scale mining or from low contributions of large companies.

(ii) in the governance terrain - it changes the governance balance between state, market actors and civil society, and it brings in international/multinational actors who interplay with domestic actors, both in the political and economic arenas. Concomitant to the macroeconomic effects, the political effects of excessive reliance on a few mineral sectors could be a reinforcement of rent-seeking behaviour, both in governments and elites.

Fourth, in countries where the institutional fiscal structure responds to national social welfare priorities, mineral revenue has the potential to positively affect the expansion of a welfare state regime. Recent experiences on social protection programmes also show that they mitigate insecurity in developing countries (for example, Bolivia's universal pensions programme: Hinojosa 2009).

Fifth, given that MDCs compete (at regional and global scales) to attract mineral FDI, and fiscal incentives are among the most used instruments, a "race-to-the-bottom" strategy significantly reduces the potential of mineral industries to produce any effect on a welfare state regime. If, in addition, states are weak and institutions are of poor quality, mineral wealth can produce weakening effects on an informal security regime (for instance, by reducing the natural resources on which rural livelihoods rely), or even strengthen some of the negative features of an insecurity regime (for instance, by creating or exacerbating conflicts). There is not enough supporting evidence that private sector measures (via corporate social responsibility/CSR) efficiently counteract to reduce such a negative impact.

Sixth, given that large-scale mineral expansion originates in institutional sites (state and market) and is shaped by civil society, and these sites are located in host and foreign countries, the domestic or international origin of actors from each site introduces a qualitative component into the decision-making process about mineral expansion (that is, the level of expansion and the conditions in which that happens). Such a qualitative component influences the degree of autonomy that domestic actors have to make decisions over their mineral endowments and, eventually, determine the impact of mineral wealth on the welfare regimes. In other words, changes within welfare regimes are defined in national and international arenas. For example, decisions on the mineral tax system, which might influence the likelihood of developing a welfare state regime, are mainly in the state domain and could be used as an instrument to enforce autonomy. Regulation for mineral activity is produced both within state and international regulatory bodies; therefore, both domestic and international actors can influence the effects of mineral wealth on change and transition of welfare regimes. The decisions of the mineral corporations and international financial institutions (IFIs) on investment location are market-based; thus, how they influence welfare regimes is subject to market forces. However, companies' direct action on welfare provision (for example, via CSR) and IFIs' conditionalities for funding mineral projects can modify those market decisions. Furthermore, as discussed in section 2, civil society's response and action can also shape market forces.

A final remark about this approach regards the connection between social policy and social change. While developing this connection goes beyond the scope of this paper, it is noteworthy 
to recall the transformative role of social policy in terms of development, social relations as well as institutions and norms (UNRISD 2006). In that sense, it is essential to explore how social policy funded by mineral resources produces particular welfare outcomes and induces a process of social change.

\section{Future Directions}

There was, until the recent economic crisis, an expectation fuelled by the last mineral boom that a primary commodity export-led growth strategy could also allow for transformative social policy. However, there have been many disappointments with mineral export-led strategies and, more recently, there has been an increasing concern about the macroeconomic, governance and peace effects induced by the expansion of the mineral industry.

The cross-section approach used in this paper to analyse 74 selected mineral-dependent developing countries has shown that the evidence is not conclusive with regard to a generalized pattern of linkages between mineral wealth, state revenue and social welfare. In order to respond to the initial concerns about how mineral wealth can contribute in enhancing social welfare in MDCs and the extent to which mineral expansion undermines the chances of social development, the relationship between state revenue and social policy needs to be addressed in an integrative framework that includes both the macroeconomic and the governance dimensions of a mineral-led development strategy. This paper aims to contribute to this.

In an ideal world, specific data about mineral production, companies' profits, mineral revenue, mineral tax revenue and public expenditure of that revenue would be available for researchers and policy makers to clearly assess the real contribution of mineral sectors to development. Unfortunately, reality is different and therefore any kind of statistics-based study should be viewed with caution. But, more important, the lack of data in the extractive industries (where colossal amounts of financial resources flow) is indicative of the weak basis on which decisions about allocation of resources are made and mechanisms for revenue mobilization are designed. Furthermore, claims about the perverse role of mineral revenue in fuelling bribes, conflicts and civil war constitute an urgent call for increasing transparency in the industry, a call that is also an opportunity for further research and policy advice in the sector.

Given that the concern about the linkages between mineral development and welfare is relatively new, social policy is a fruitful domain where mineral wealth can make a contribution if the mechanisms that facilitate informed and socially sound decisions are in place. Along that line, country and comparative case studies on the effects of mineral production and expansion on welfare regimes can be insightful for social policy design. Enquiry about the effects of mineral expansion on the emergence and development of domestic markets (particularly labour and financial markets) can also contribute to social policy finance and delivery. Finally, if social policy can certainly play an instrumental role and, by doing so, produce social transformation, there is much to explore regarding the structural and institutional conditions in which the connection between mineral production and expansion and social policy can lead development. 
Annex: Social Insurance and Social Assistance Programmes in Selected Mineral-Dependent Economies (Operating in March 2008) ${ }^{a}$

\begin{tabular}{|c|c|c|c|c|}
\hline Economy & $\begin{array}{l}\text { Mineral export- } \\
\text { dependence }\end{array}$ & $\begin{array}{c}\text { Social } \\
\text { insurance }\end{array}$ & $\begin{array}{c}\text { Social } \\
\text { assistance }\end{array}$ & Salient features \\
\hline \multicolumn{5}{|l|}{ Fuel dependent } \\
\hline Nigeria & $\mathrm{h}$ & I & none & $\begin{array}{l}\text { School feeding and community } \\
\text { development programme (World } \\
\text { Bank); pilot child subsidy in process } \\
\text { of implementation }\end{array}$ \\
\hline Algeria & $\mathrm{h}$ & $\mathrm{h}$ & none & \\
\hline Yemen & $\mathrm{h}$ & & none & \\
\hline Venezuela & $\mathrm{h}$ & $\mathrm{m}$ & I & \\
\hline Gabon & $\mathrm{h}$ & none & none & \\
\hline Turkmenistan & $\mathrm{h}$ & & & $\begin{array}{l}\text { Pension and family allowances } \\
\text { reform }\end{array}$ \\
\hline Sudan & $\mathrm{h}$ & I & & \\
\hline Azerbaijan & $\mathrm{h}$ & & & Pension reform \\
\hline Equatorial Guinea & $\mathrm{h}$ & none & none & \\
\hline Angola & $\mathrm{h}$ & none & none & \\
\hline Russian Federation & $\mathrm{h}$ & $\mathrm{m}$ & $\mathrm{m}$ & Pension reform \\
\hline Cameroon & $\mathrm{h}$ & 1 & none & \\
\hline Ecuador & $\mathrm{h}$ & $\mathrm{m}$ & $\mathrm{m}$ & $\begin{array}{l}\text { Bono de Desarrollo Humano- } \\
\text { conditional cash transfer (CCT) }\end{array}$ \\
\hline Egypt & $\mathrm{h}$ & $\mathrm{m}$ & I & $\begin{array}{l}\text { New integrated poverty reduction } \\
\text { programme (similar to Chile } \\
\text { Solidario) }\end{array}$ \\
\hline Cape Verde & $\mathrm{m}$ & I & $\mathrm{m}$ & $\begin{array}{l}\text { Social pension just being introduced } \\
\text { (ILO Strategies and Tools against } \\
\text { Social Exclusion and Poverty/STEP) }\end{array}$ \\
\hline Colombia & $\mathrm{m}$ & $\mathrm{m}$ & $\mathrm{m}$ & $\begin{array}{l}\text { Familias en Acción-upscaled CCT; } \\
\text { pension and health insurance } \\
\text { reform in mid-1990s }\end{array}$ \\
\hline Seychelles & $\mathrm{m}$ & & & \\
\hline Indonesia & $\mathrm{m}$ & I & $\mathrm{m}$ & $\begin{array}{l}\text { New safety nets programme-- } \\
\text { CCT-and health insurance }\end{array}$ \\
\hline Maldives & $\mathrm{m}$ & $\mathrm{m}$ & & \\
\hline Viet Nam & $\mathrm{m}$ & I & I & \\
\hline Senegal & I & I & I & $\begin{array}{l}\text { Small programmes on vulnerable } \\
\text { groups-community health } \\
\text { insurance (ILO) }\end{array}$ \\
\hline Lithuania & I & $\mathrm{h}$ & $\mathrm{m}$ & Pension reform in 1990 s as in Chile \\
\hline Argentina & I & $\mathrm{m}$ & $\mathrm{m}$ & New social pension and CCT \\
\hline Uzbekistan & I & $\mathrm{m}$ & $\mathrm{m}$ & Pension reform \\
\hline Myanmar & I & none & & \\
\hline Kenya & I & I & $\mathrm{m}$ & $\begin{array}{l}\text { New orphan and vulnerable children } \\
\text { transfer programme and food } \\
\text { security }\end{array}$ \\
\hline Kyrgyzstan & I & $\mathrm{m}$ & $\mathrm{m}$ & Social assistance reform (1998) \\
\hline Mexico & I & $\mathrm{m}$ & $\mathrm{m}$ & $\begin{array}{l}\text { Pension reform in } 1990 \text { s, more } \\
\text { recently CCT Oportunidades, and } \\
\text { health insurance for poor, Progresa } \\
\text { programme }\end{array}$ \\
\hline
\end{tabular}




\begin{tabular}{|c|c|c|c|c|}
\hline Economy & $\begin{array}{l}\text { Mineral export- } \\
\text { dependence }\end{array}$ & $\begin{array}{c}\text { Social } \\
\text { insurance }\end{array}$ & $\begin{array}{c}\text { Social } \\
\text { assistance }\end{array}$ & Recent reform; highlight \\
\hline \multicolumn{5}{|c|}{ Mineral and ores dependent } \\
\hline Botswana & $\mathrm{h}$ & $\mathrm{h}$ & $\mathrm{h}$ & $\begin{array}{l}\text { Social assistance is dominant, } \\
\text { pension and child grants }\end{array}$ \\
\hline Suriname & $\mathrm{h}$ & I & 1 & \\
\hline Zambia & $\mathrm{h}$ & I & I & $\begin{array}{l}\text { Social insurance for civil servants } \\
\text { only; pension reform; four pilot } \\
\text { transfer programmes; reliance on } \\
\text { food aid }\end{array}$ \\
\hline Jamaica & $\mathrm{h}$ & I & $\mathrm{m}$ & $\begin{array}{l}\text { New CCT Programme for } \\
\text { Advancement through Health and } \\
\text { Education (PATH) }\end{array}$ \\
\hline Guinea & $\mathrm{h}$ & & none & \\
\hline Mongolia & $\mathrm{h}$ & $\mathrm{m}$ & I & $\begin{array}{l}\text { Child school subsidy, United Nations } \\
\text { Children's Fund (UNICEF) }\end{array}$ \\
\hline Chile & $\mathrm{h}$ & $\mathrm{h}$ & $\mathrm{h}$ & $\begin{array}{l}\text { Strong social insurance and } \\
\text { assistance (Chile Solidario). } \\
\text { Structural reform of pension system } \\
(1980-1981)\end{array}$ \\
\hline Tajikistan & $\mathrm{h}$ & $\mathrm{m}$ & I & \\
\hline Peru & $\mathrm{m}$ & $\mathrm{m}$ & I & $\begin{array}{l}\text { New Juntemonos CCT with } \\
\text { community component }\end{array}$ \\
\hline Ghana & $\mathrm{m}$ & I & I & New CCT and health insurance \\
\hline Cuba & $\mathrm{m}$ & $\mathrm{h}$ & & \\
\hline Nepal & $\mathrm{m}$ & I & $\mathrm{m}$ & New social pension universal \\
\hline Rwanda & $\mathrm{m}$ & none & none & \\
\hline $\begin{array}{l}\text { Central African } \\
\text { Republic }\end{array}$ & $\mathrm{m}$ & & none & \\
\hline Armenia & I & $\mathrm{m}$ & $\mathrm{m}$ & \\
\hline Georgia & I & $\mathrm{m}$ & $\mathrm{m}$ & \\
\hline $\begin{array}{l}\text { Bosnia and } \\
\text { Herzegovina }\end{array}$ & I & $\mathrm{m}$ & & \\
\hline Zimbabwe & I & I & none & \\
\hline South Africa & I & none & $\mathrm{h}$ & $\begin{array}{l}\text { Social assistance is dominant, } \\
\text { pension and child grants }\end{array}$ \\
\hline Namibia & I & none & $\mathrm{h}$ & $\begin{array}{l}\text { Social assistance is dominant, } \\
\text { pension and child grants }\end{array}$ \\
\hline Benin & I & none & none & \\
\hline Guyana & 1 & I & I & \\
\hline \multicolumn{5}{|c|}{ Fuels, mineral and ores dependent } \\
\hline Kazakhstan & $\mathrm{h}$ & $\mathrm{m}$ & $\mathrm{m}$ & Pension reform \\
\hline Bolivia & $\mathrm{h}$ & I & $\mathrm{m}$ & $\begin{array}{l}\text { Universal social pension funded by } \\
\text { privatization fund-recent re- } \\
\text { nationalization in the fuels sector } \\
\text { undermines funding ( } 50 \text { per cent of } \\
\text { capitalization funds from fuel } \\
\text { companies) }\end{array}$ \\
\hline Mozambique & $\mathrm{h}$ & I & I & Small social assistance \\
\hline $\begin{array}{l}\text { Democratic Republic } \\
\text { of the Congo }\end{array}$ & $\mathrm{m}$ & none & none & \\
\hline
\end{tabular}

Notes: ${ }^{\mathrm{a}} \mathrm{h}=$ high dependence: more than 40 per cent; $\mathrm{m}=$ medium dependence: $20-39$ per cent; $\mathrm{I}=$ low dependence: $10-19$ per cent.

Source: A. Barrientos's database. 


\section{Bibliography}

Addison, Tony. 2003. "Introduction." In Tony Addison (ed.), From Conflict to Recovery. Oxford University Press, New York.

Adésínà, 'Jìmí. 2008. Social Policy in a Mineral-Rich Economy: The Case of Nigeria. Mimeo. Paper prepared for the UNRISD project on Social Policy in Mineral-Rich Countries. UNRISD, Geneva.

Arjan de Haan, Anis. 2007. Reclaiming Social Policy: Globalization, Social Exclusion and New Poverty Reduction Strategies. Palgrave Macmillan, Basingstoke.

Auty, Richard. 2008. "From mining enclave to economic catalyst: Large mineral projects in developing countries." Brown Journal of World Affairs, Vol. 13, No. 1, pp. 135-145.

(ed.). 2001. Resource Abundance and Economic Development. Oxford University Press, Oxford. 1993. Sustaining Development in Mineral Economies: The Resource Curse Thesis. Routledge, London.

Auty, Richard and Alan Gelb. 2001. "Political economy of resource-abundant states." In Richard Auty (ed.), Resource Abundance and Economic Development. Oxford University Press, Oxford.

Bebbington, Anthony (ed.). 2007. Minería, Movimientos Sociales y Respuestas Campesinas: Una Ecología Política de Transformaciones Territoriales. IEP, Lima.

Bebbington, Anthony and Maria Burneo. 2008. "Conflictos mineros: Freno al desarrollo o expresión ciudadana." In Oxfam GB, Pobreza y Desarrollo en el Perú: Informe Anual 2007-2008. Oxfam GB, Lima.

Bebbington, Anthony, Michael Connarty, Wendy Coxshall, Hugh O'Shaughnessy and Mark Williams. 2007. Mining and Development in Peru: With Special Reference to the Rio Blanco Project, Piura. Peru Support Group, London.

Bebbington, Anthony and Leonith Hinojosa. 2007. "Conclusiones: Minería, neoliberalización y reterritorialización del desarrollo rural." In Anthony Bebbington (ed.), Minería, Movimientos Sociales y Respuestas Campesinas. Una Ecología Política de Transformaciones Territoriales. IEP, Lima.

Bebbington, Anthony, Leonith Hinojosa, Denise H. Bebbington, Maria Luisa Burneo and Ximena Warnaars. 2008. "Contention and ambiguity: Mining and the possibilities of development." Development and Change, Vol. 39, No. 6, pp. 887-914.

Beblawi, Hazem. 1987. "The rentier state in the Arab world." In Hazem Beblawi and Giacomo Luciani (eds.), The Rentier State. Croom Helm, New York.

Brunnschweiler, C.N. and E.H. Bulte. 2008. "Linking natural resources to slow growth and more conflict." Science, Vol. 320, No. 5876, 2 May, pp. 616-617.

Carlson, Anthony. 2006. "Mineral wealth: The cry from the Democratic Republic of Congo." Harvard International Review, Summer, p. 6.

Clark, Allen and Koh Naito. 1998. "Risks and opportunities for foreign investment in the mineral sectors of the Central Asian Republics: Kazakhstan, Kyrgyzstan, Tajikistan and Uzbekistan." Resources Policy, Vol. 24, No. 2, pp. 105-114.

1997. "Structural reform of the mining industry in Asia and the Pacific region." Asian Journal of Mining, July-August, pp. 28-42.

Collier, Peter and A. Hoeffler. 2005. "Resource rents, governance, and conflict." Journal of Conflict Resolution, Vol. 49, No. 4, pp. 625-633.

Davis, Graham. 2007. "Mining royalties: A global study of their impact on investors, government, and civil society (book review)." Resources Policy, Vol. 32, No. 3, p. 146.

-1995. "Learning to love the Dutch disease: Evidence from the mineral economies." World Development, Vol. 23, No. 10, pp. 1765-1779.

Development Solutions, CEPR (Centre for Economic Policy Research) and University of Manchester. 2009. EU-Andean Trade Sustainability Impact Assessment. Report commissioned by the European Commission DG Trade. http://trade.ec.europa.eu/doclib/docs/2009/july/ tradoc_144011.pdf, accessed on October 2009.

De Soysa, Indra and Eric Neumayer. 2007. "Resource wealth and the risk of civil war onset: Results from a new dataset of natural resource rents." Conflict Management and Peace Science, Vol. 24, No. 3, pp. 201-218.

Dietsche, Evelyn. 2008. Institutional Change and Developmental State Capacity in Mineral-Rich Countries. Mimeo. Paper prepared for the UNRISD project on Social Policy in Mineral-Rich Countries. UNRISD, Geneva. 
ECLAC (Economic Commission for Latin America and the Caribbean). 2002. Foreign Investment in Latin America and the Caribbean 2001. United Nations, Santiago de Chile.

Esping-Andersen, Gøsta. 2001. "Social welfare policy: Comparisons." In Neil J. Smelser and Paul B. Baltes (eds.), International Encyclopedia of the Social and Behavioral Sciences. Pergamon, Oxford.

- 1999. Social Foundations of Postindustrial Economies. Oxford University Press, Oxford. 1990. The Three Worlds of Welfare Capitalism. Polity Press, Cambridge.

Fearon, James and David Laitin. 2003. "Ethnicity, insurgency, and civil war." American Political Science Review, Vol. 97, No. 1, pp. 75-90.

Frynas, Jedrzej George. 2005. "The false developmental promise of corporate social responsibility: Evidence from multinational oil companies." International Affairs, Vol. 81, No. 3, pp. 581-598.

Garnaut, Ross and Anthony Clunies-Ross. 1983. Taxation of Mineral Rents. Clarendon Press, Oxford.

Gelb, Alan and associates. 1988. Oil Windfalls: Blessing or Curse? Oxford University Press, New York.

Goolsbee, Austan. 2004. "Taxes and the quality of capital." Journal of Public Economics, Vol. 88, Nos. 3-4, pp. 519-543.

Gough, Ian and Geof Wood, with Armando Barrientos, Philippa Bevan, Peter Davis and Graham Room. 2004. Insecurity and Welfare Regimes in Asia, Africa and Latin America. Cambridge University Press, Cambridge.

Gould, John and Matthew Winters. 2007. "An obsolescing bargain in Chad: Shifts in leverage between the government and the World Bank." Business and Politics, Vol. 9, No. 2, pp. 1-34.

Guajardo, J. Carlos. 2008. Mineral Rents and Social Development in Chile. Mimeo. Paper prepared for the UNRISD project on Social Policy in Mineral-Rich Countries. UNRISD, Geneva.

Gylfason, Thorvaldur. 2008. Development and Growth in Mineral-Rich Countries. Mimeo. Paper prepared for the UNRISD project on Social Policy in Mineral-Rich Countries. UNRISD, Geneva.

_. 2001. "Natural resources, education, and economic development." European Economic Review 45 , pp. $847-859$.

Hall, Anthony and James Midgley. 2004. Social Policy for Development. Sage, London.

Hilson, Gavin and N. Yakovelva. 2007. "Strained relations: A critical analysis of the mining conflict in Prestea, Ghana." Political Geography, Vol. 26, No. 1, pp. 98-119.

Hinojosa, Leonith. 2009. Riqueza Mineral y Pobreza en los Andes. Paper presented at the Congress of the Latin American Studies Association, Rio de Janeiro, Brazil, 11-14 June.

Hinojosa, Leonith and Anthony Bebbington. 2010. "Transnational companies and transnational civil society." In Kean Birch and Vlad Mykhnenko (eds.), The Rise and Fall of Neoliberalism: The Collapse of an Economic Order? Zed Books, London.

ICMM (International Council on Mining and Metals). 2006. Resource Endowment Initiative: The Analytical Framework. ICMM, UNCTAD and World Bank, London.

IMF (International Monetary Fund). 2009. World Economic Outlook: Crisis and Recovery. IMF, Washington, DC

—. 2007. The Role of Fiscal Institutions in Managing the Oil Revenue Boom. IMF, Washington, DC.

Isham, Jonathan, Michael Woolcock, Lant Pritchett and Gwen Busby. 2005. "The varieties of resource experience: Natural resource export structures and the political economy of economic growth." The World Bank Economic Review, Vol. 19, No. 2, pp. 141-174.

Jensen, Nathan and Leonard Wantchekon. 2004. "Resource wealth and political regimes in Africa." Comparative Political Studies, Vol. 37, No. 7, pp. 816-841.

Jones Luong, Pauline and Erika Weinthal. 2001. "Prelude to the resource curse: Explaining oil and gas development strategies in the Soviet successor states and beyond." Comparative Political Studies, Vol. 34, No. 4, pp. 367-399.

Jordan, Rolando and Alyson Warhurst. 1992. "The Bolivian mining crisis." Resources Policy, Vol. 18, No. 1, pp. 9-20.

Karl, Lynn. 1997. The Paradox of Plenty: Oil Booms and Petro-States. University of California Press, Berkeley.

Karl, Lynn and J. Cleveland Cutler. 2004. "Oil-led development: social, political, and economic consequences." In Encyclopedia of Energy. Elsevier, New York.

Kumar, Raj. 1991. "Taxation for a cyclical industry." Resources Policy, Vol. 17, No. 2, pp. $133-148$. 
Lewis, Peter. 2007. Growing Apart: Oil, Politics and Economic Change in Indonesia and Nigeria. University of Michigan Press, Ann Arbor.

Manby, Bronwen. 1999. "The role and responsibility of oil multinationals in Nigeria." Journal of International Affairs, Vol. 53. No. 1, pp. 281-301.

Matshediso, I.B. 2005. "A review of mineral development and investment policies of Botswana." Resources Policy, Vol. 30, No. 3, p. 203.

Meller, Patricio, Raul O'Ryan and Andres Solimano. 1996. "Growth, equity, and the environment in Chile: Issues and evidence." World Development, Vol. 24, No. 2, p. 255.

Mkandawire, Thandika. 2004. Social Policy in a Development Context. UNRISD and Palgrave Macmillan, Basingstoke.

Neumayer, Eric. 2004. "Does the 'resource curse' hold for genuine income as well?" World Development, No. 32, pp. 1627-1640.

O'Faircheallaigh, Ciaran. 1998. "Indigenous people and mineral taxation regimes." Resources Policy, Vol. 24, No. 4, p. 187.

Otto, James M. 2000. "Investing for sustainability: The management of mineral wealth." Resources Policy, Vol. 28, Nos. 1-2, pp. 78-80.

Otto, James, Craig Andrews, Michael Doggett, Pietro Guj, Frank Stermole, John Stermole and John Tilton. 2007. Mining Royalties: A Global Study of Their Impact on Investors, Government, and Civil Society. World Bank, Washington, DC.

Pegg, Scott. 2006a. "Mining and poverty reduction: Transforming rhetoric into reality." Journal of Cleaner Production, Vol. 14, No. 3-4, pp. 376-387.

_ 2006b. "World leaders and bottom feeders: Divergent strategies toward social responsibility and resource extraction." In Christopher May (ed.), Global Corporate Power. Lynne Rienner Boulder, CO.

_. 1999. "Transnational corporations and violence in Nigeria." Security Dialogue, Vol. 30, No. 4, pp. 473-484.

Powell, Martin and Armando Barrientos. 2004. "Welfare regimes and the welfare mix." European Journal of Political Research, Vol. 43, No. 1, pp. 83-105.

Riesco, Manuel, Gustavo Lagos and Marcos Lima. 2005. The "Pay Your Taxes" Debate: Perspectives on Corporate Taxation and Social Responsibility in the Chilean Mining Industry. Programme on Technology, Business and Society, Paper No. 16. UNRISD, Geneva.

Ross, Michael. 2001. "Does oil hinder democracy?" World Politics, Vol. 53, No. 3, pp. 325-361.

2004. "What do we know about natural resources and civil war?" Journal of Peace Research, Vol. 41, No. 3, pp. 337-356.

Rosser, Andrew. 2009. "Natural resource wealth, development and social policy: Evidence and issues." In Katja Hujo and Shea McClanahan (eds.), Financing Social Policy: Mobilizing Resources for Social Development. Palgrave Macmillan, Basingstoke.

. 2006. "Escaping the resource curse." New Political Economy, Vol. 11, No. 4, pp. 557-570.

Sachs, Jeffrey and Andrew Warner. 2001. "The curse of natural resources." European Economic Review, Vol. 45, Nos. 4-6, pp. 827-838.

- 1995. Natural Resource Abundance and Economic Growth. NBER Working Paper Series, Working Paper No. 5398, pp. 1-47.

Sarma, J.V.M. and Gautam Naresh. 2001. "Mineral taxation around the world: Trends and issues." Asia-Pacific Tax Bulletin, January.

Sarraf, Maria and Moortaza Jiwanji. 2001. Beating the Resource Curse: The Case of Botswana. World Bank Environment Department Papers, Environmental Economics Series. World Bank, Washington, DC.

Shaxson, Nicholas. 2007. Poisoned Wells. The Dirty Politics of African Oil. Palgrave Macmillan, New York.

—. 2005. "New approaches to volatility: Dealing with the 'resource curse' in sub-Saharan Africa." International Affairs, Vol. 81, No. 2, pp. 311-324.

Smith, Benjamin. 2007. Hard Times in the Lands of Plenty: Oil Politics in Iran and Indonesia. Cornell University Press, Ithaca, NY.

Stijns, Jean-Philippe. 2006. "Natural resource abundance and human capital accumulation." World Development, Vol. 34, No. 6, pp. 1060-1083. 
2005. "Natural resource abundance and economic growth revisited." Resources Policy, Vol. 30, No. 2, pp. 107-130.

Timmer, Peter. 2004. The Road to Pro-Poor Growth: The Indonesian Experience in Regional Perspective. Working Papers, No. 38. Center for Global Development, Washington, DC.

Titmuss, Richard M. 1974. Social Policy. An Introduction (course of introductory lectures given by the author and edited by Brian Abel-Smith and Kay Titmuss.) Allen and Unwin, London.

UNCTAD (United Nations Conference on Trade and Development). 2007. World Investment Report 2007: Transnational Corporations, Extractive Industries and Development. United Nations, New York.

UNRISD (United Nations Research Institute for Social Development). 2006. Transformative Social Policy: Lessons from UNRISD Research. UNRISD Research and Policy Brief, No. 5. UNRISD, Geneva.

Wade, Robert Hunter. 1992. "East Asia's economic success: Conflicting perspectives, partial insights, shaky evidence." World Politics, No. 44, pp. 270-320.

Willmore, Larry. 2007. "Universal pensions for developing countries." World Development, Vol. 35, No. 1 , pp. 24-51.

Wood, Geof and Ian Gough. 2006. "A comparative welfare regime approach to global social policy." World Development, Vol. 34, No. 10, p. 1696.

World Bank. 2006. Country Policy and Institutional Assessments: Assessment Questionnaire. World Bank, Washington, DC.

- 2005. Extractive Industries and Sustainable Development. An Evaluation of World Bank Group Experience. World Bank, IFC and MIGA, Washington, DC.

- (ed.). 2002. A Sourcebook for Poverty Reduction Strategies. Volume 2: Macroeconomic and Sectoral Approaches. World Bank, Washington, DC.

- 1996. Latin America and the Caribbean: A Mining Strategy. World Bank Technical Paper No. 345. Industry and Mining Division. World Bank, Washington, DC.

Yates, Douglas. 1996. The Rentier State in Africa. Africa World Press, Trenton, NJ. 



\section{UNRISD Programme Papers on Social Policy and Development}

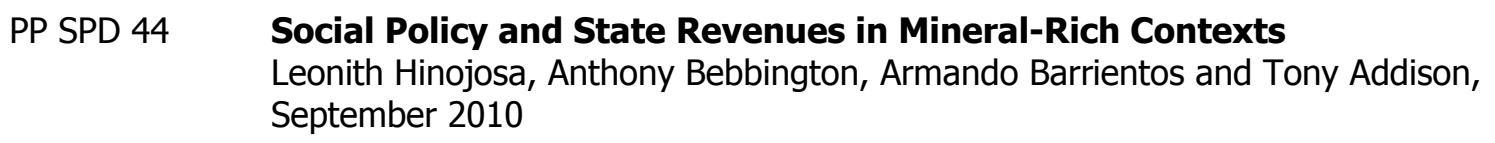

PP SPD 43 Social Relations and Associations in the Informal Sector in Kenya Mary Njeri Kinyanjui, January 2010

PP SPD 42 Social Protection and Poverty

Armando Barrientos, January 2010

PP SPD 41 The Implications of Migration for Gender and Care Regimes in the South

Eleonore Kofman and Parvati Raghuram, July 2009

PP SPD $40 \quad$ Migration and Poverty: Linkages, Knowledge Gaps and Policy Implications

Arjan de Haan and Shahin Yaqub, June 2009

PP SPD 39 Migration and Social Development: Organizational and Political Dimensions

Nicola Piper, May 2009

PP SPD 38 The Private Affairs of Public Pensions in South Africa: Debt, Development and Corporatization

Fred Hendricks, December 2008

PP SPD 37 Explaining Ireland's Development: Economic Growth with Weakening Welfare

Peadar Kirby, September 2008

PP SPD 36 Social Insurance (Pensions and Health), Labour Markets and Coverage in Latin America

Carmelo Mesa-Lago, August 2008

PP SPD $35 \quad$ Successful Targeting? Reporting Efficiency and Costs in Targeted Poverty Alleviation Programmes

Alexander Peyre Dutrey, November 2007

PP SPD 34 Remittances, Migration and Social Development: A Conceptual

Review of the Literature

Hein de Haas, October 2007

PP SPD 33 Social Policy and the Quest for Inclusive Development:

Research Findings from Sub-Sahara Africa

'Jìmí O. Adésínà, May 2007

PP SPD 32 How Far Does It Go? The Buenos Aires Water Concession a Decade after the Reform

José A. Delfino, Ariel A. Casarin and María Eugenia Delfino, May 2007

PP SPD 31 Public Pensions in a Development Context: The Case of Canada Ken Battle and Edward Tamagno, February 2007

PP SPD 30 Implicações do Financiamento do Banco Mundial para as respostas das ONGs e OBCs ao HIV/Aids no Sul e Sudeste do Brasil

Elisabete Inglesi, com Ana Lucia Weinstein, Celi Denise Cavallari, Octavio Valente Junior e Glaury Coelho, dezembro 2006

PP SPD 29 Historia del sector sanitario chileno: De la gestión estatal hasta el proceso de privatización

María Angélica Alegría Calvo y Eugenio Celedón Cariola, diciembre 2006 
$\begin{array}{ll}\text { PP SPD } 28 & \text { The Politics of HIV/AIDS in Uganda } \\ \text { Joseph Tumushabe, August } 2006\end{array}$

PP SPD 27 Neither Public Nor Private: Unpacking the Johannesburg

Water Corporatization Model

Laila Smith, May 2006

PP SPD $26 \quad$ Liberalization and HIV in Kerala

Sandhya Srinivasan and Mini Sukumar, April 2006

PP SPD 25 Pensions and Pension Funds in the Making of a Nation-State and a National Economy: The Case of Finland

Olli E. Kangas, March 2006

PP SPD 24 Mozambique's HIV/AIDS Pandemic: Grappling with

Apartheid's Legacy

Carole J.L. Collins, February 2006

PP SPD 23 Targeting and Universalism in Poverty Reduction

Thandika Mkandawire, December 2005

PP SPD 22 Transforming the Developmental Welfare State in East Asia

Huck-ju Kwon, September 2005

PP SPD 21 The Politics of Welfare Developmentalism in Hong Kong

Eliza W.Y. Lee, August 2005

PP SPD 20 Política social y reforma social "a la tica": Un caso paradigmático de heterodoxia en el contexto de una economía periférica Manuel Barahona, Ludwig Güendel y Carlos Castro, agosto 2005

PP SPD 19 The Adult Worker Model, Gender Equality and Care:

The Search for New Policy Principles, and the Possibilities

and Problems of a Capabilities Approach

Susy Giullari and Jane Lewis, April 2005

PP SPD 18 "Globalization" and Social Policy in a Development

Context: Regional Responses

Nicola Yeates, April 2005

PP SPD 17 The Developmental Welfare State in Scandinavia:

Lessons for the Developing World

Stein Kuhnle and Sven E.O. Hort, September 2004

PP SPD 16 Late Industrializers and the Development of the Welfare State Christopher Pierson, September 2004

PP SPD 15 Global Capitalism, Deflation and Agrarian Crisis in Developing Countries Utsa Patnaik, July 2003

PP SPD 14 Agrarian Change, Gender and Land Rights: A Brazilian Case Study Julia S. Guivant, June 2003

PP SPD 13 Reworking Apartheid Legacies: Global Competition, Gender and Social Wages in South Africa, 1980-2000

Gillian Hart, December 2002

PP SPD 12 Women's Employment and Welfare Regimes: Globalization, Export Orientation and Social Policy in Europe and North America Ann Shola Orloff, June 2002

PP SPD 11 Agrarian Reform, Gender and Land Rights in Uzbekistan Deniz Kandiyoti, June 2002

PP SPD 10 Agrarian Change, Gender and Land Reform: A South African Case Study Cherryl Walker, April 2002 


\begin{tabular}{|c|c|}
\hline PP SPD 9 & $\begin{array}{l}\text { Gender and Education: A Review of Issues for Social Policy } \\
\text { Ramya Subrahmanian, April } 2002\end{array}$ \\
\hline PP SPD 8 & $\begin{array}{l}\text { Dynamique de la politique sociale en Côte d'Ivoire } \\
\text { Francis Akindès, juillet } 2001\end{array}$ \\
\hline PP SPD 7 & $\begin{array}{l}\text { Social Policy in a Development Context } \\
\text { Thandika Mkandawire, June } 2001\end{array}$ \\
\hline PP SPD 6 & $\begin{array}{l}\text { Breaking the Mould: An Institutionalist Political Economy } \\
\text { Alternative to the Neoliberal Theory of the Market and the State } \\
\text { Ha-Joon Chang, May } 2001\end{array}$ \\
\hline PP SPD 5 & $\begin{array}{l}\text { Les politiques sociales en Afrique de l'Ouest: Quels changements } \\
\text { depuis le Sommet de Copenhague? Synthèse des études de cas } \\
\text { (Bénin, Burkina Faso, Côte d'Ivoire, Mali, Sénégal) } \\
\text { Momar-Coumba Diop, avril } 2001\end{array}$ \\
\hline PP SPD 4 & $\begin{array}{l}\text { AIDS in the Context of Development } \\
\text { Joseph Collins and Bill Rau, December } 2000\end{array}$ \\
\hline PP SPD 3 & $\begin{array}{l}\text { Empirical Inquiries and the Assessment of Social Progress } \\
\text { in Western Europe: A Historical Perspective } \\
\text { Jean-Michel Collette, June } 2000\end{array}$ \\
\hline PP SPD 2 & $\begin{array}{l}\text { Social Indicators and Welfare Monitoring } \\
\text { Gøsta Esping-Andersen, May } 2000\end{array}$ \\
\hline PP SPD 1 & $\begin{array}{l}\text { External Dependency and Internal Transformation: } \\
\text { Argentina Confronts the Long Debt Crisis } \\
\text { Jorge Schvarzer, May } 2000\end{array}$ \\
\hline
\end{tabular}


Printed at the United Nations, Geneva GE.10-01906-September 2010-1,400 